Historic, archived document

Do not assume content reflects current scientific knowledge, policies, or practices. 

62
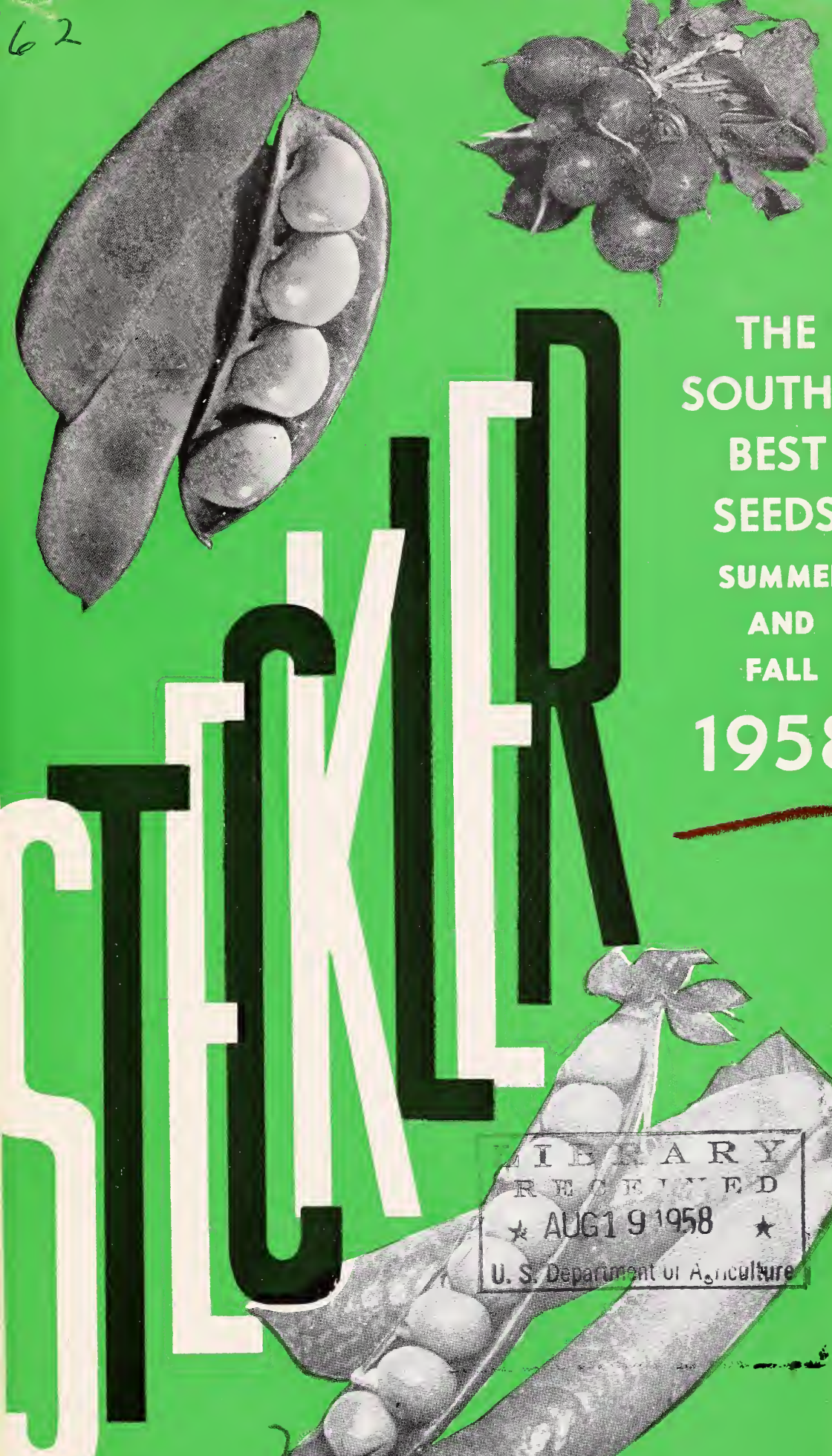
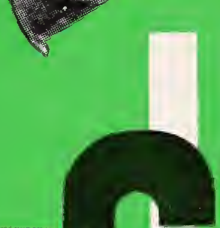

THE SOUTH'S BEST SEEDS SUMMER AND FALL 1958

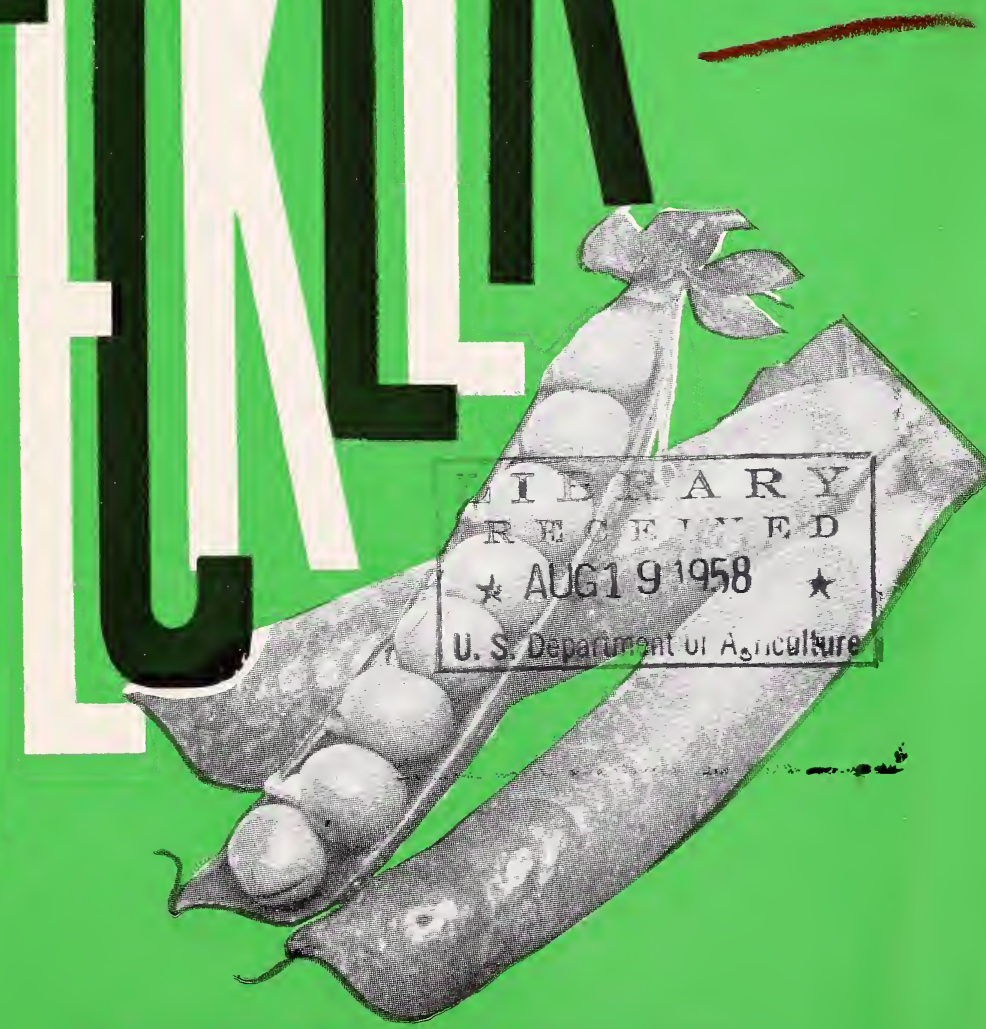

STECKLER SEED COMPANY, INC. 512 exavio: NEW ORLEANS 3, LA. 


\section{bulbs for spring}

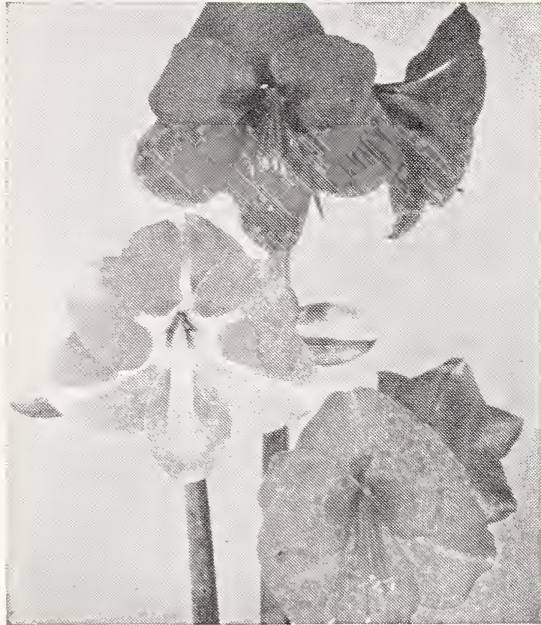

Amaryllis

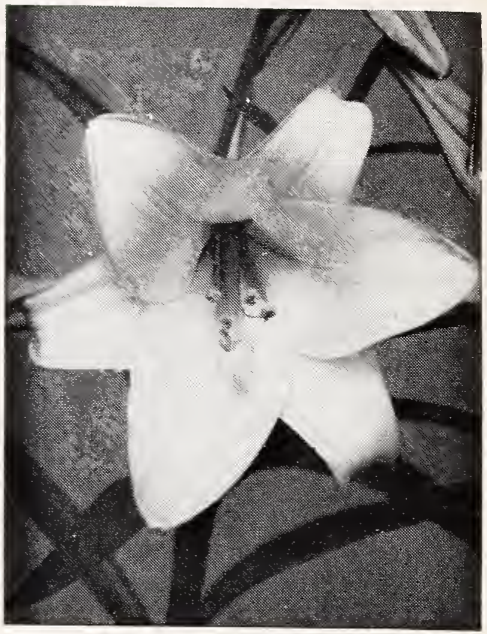

Easter Lily

CALLA LILIES-Highly decorative pot-plants with large, showy funnel-shaped flowers. Aethiopica-Best pearl-white Calla Lily for amateurs. It is easily grown, and blooms most prolifically. Strong roots. Each $45 \mathrm{c} ; 6$ for $\$ 2.35 ; 12$ for $\$ 4.25$ postpaid.

Elliotiana-Extremely snowy, with large, lustrous, golden yellow flowers. Each 35c; 6 for $\$ 1.85$; 12 for $\$ 3.50$, postpaid.

Arum Pictum (Black Calla)-Same as white and odorless. Each 65c, postpaid.

Richardia Rehmanii Superba (Pink Calla)-Large flowered, tall, light pink. Each 45c, postpaid.

CHINESE SACRED LILY (Joss Flower or Flower of the Gods)-The flowers are white with $\alpha$ yellow cup in the center and very fragrant. Each 25c; 6 for $\$ 1.25 ; 12$ for $\$ 2.00$.

CREOLE EASTER LILY - This majestic and charming Lily is a product of Louisiana, and is the finest of all Easter Lillies. Bulbs may be planted during the months of October, November and December.

Bulbs: Each 35c; 6 for $\$ 1.85 ; 12$ for $\$ 3.50$.

Mammoth bulbs: Each 60c; 6 for $\$ 3.00 ; 12$ for $\$ 5.50$.

LILIUM REGALE-Free blooming, trumpet shaped, delicately scented white blossoms, tinted with pink. Each 45c; 6 for $\$ 2.25$

LILIUM CANDIDUM (Madonna Lily)-Popular old fashioned lilies with waxy white petals and heavy yellow stamens. Prefer sandy soil and sunny location. Each 45c; 6 for $\$ 2.50 ; 12$ for $\$ 4.50$.

LILIUM SPECIOSUM RUBRUM-Hardy perfect lily, deep rose with brilliant bordeaux specks and shadings. Blooms June and July. Each 75c.

AMARYLLIS (Giant-Flowered)-New Hybrids. This giant flowered strain is a mixture of colors, ranging from the darkest red through striped and light shades. Each 55c; 12 for $\$ 5.00$, postpaid.

Pure White

\section{AMARYLLIS (Giant Super Deluxe)}

$$
\begin{array}{ll}
\text { S2.50 each } & \text { Salmon } \\
2.00 \text { each } & \text { Orange }
\end{array}
$$

$\$ 2.00$ each

Dark Red 2.00 each

ANEMONES-Poppy flowered. Spring flowering with large beautiful blooms. Roots should be soaked over night in lukewarm water before planting. Plants prefer partial shade. 6 for $60 \mathrm{c} ; 12$ for $\$ 1.00$; 100 for $\$ 5.25$, postpaid.

ST. BRIDGID-Giant semidouble flowering mixed. 6 for $75 \mathrm{c} ; 12$ for $\$ 1.00 ; 100$ for $\$ 5.25$, postpaid.

CHIONODOXA LUCILEA-(Glory of the Snow)-Clear blue flower with white center, excellent for rockeries, blooms in early spring. Doz. $75 \mathrm{c} ; 100$ for $\$ 3.00$, postpaid.

OXALIS-Mixed. Small plants with clover-like foliage and single blooms. Mixed. 6 for $60 c ; 12$ for $\$ 1.00 ; 100$ for $\$ 5.00$, postpaid.

BERMUDA BUTTERCUP-Yellow, 6 for $60 \mathrm{c} ; 12$ for $\$ 1.00 ; 100$ for $\$ 5.00$, postpaid.

SCILLAS-Blue, White, and Rose-Small bell-shaped blooms on long spikes. Plant prerers sunny location and well drained soil. 6 for $50 \mathrm{c} ; 12$ for $90 \mathrm{c}$.

RANUNCULUS-Dwarf spring flowers deserving more extensive use. The blooms are fully double and appear in many bright colors and combinations. Mixed-All colors! Each $11 \mathrm{c} ; 6$ for $55 \mathrm{c}$; 12 for $\$ 1.00$; 100 for $\$ 6.50$.

SNOWFLAKES-Everybody knows the Snowflakes, with their little white bells coming through the snow very early in the spring. Attractive if planted with Scilla. Height five inches. Pure White, 6 for $75 \mathrm{c} ; 12$ for $\$ 1.35 ; 100$ for $\$ 8.00$.

FREESIAS-Bequtiful clusters of frogrant white flowers, popular for pot culture, flowering in winter and spring. Readily forced. Plant four to six in a pot giving plenty of water and cool location.

Purity Refracta-Pure white, 6 for $55 \mathrm{c} ; 12$ for $\$ 1.00 ; 100$ for $\$ 5.00$.

Rainbow Mixed-Lovely mixture, 6 for $55 \mathrm{c}$; 12 for $\$ 1.00$; 100 for $\$ 5.00$.

GRAPE HYACINTHS-Charming dwarf plants producing hyacinth-like heads of droopY bell-shaped flowers.

Heavenly Blue-Largest and finest blue. 6 for $40 \mathrm{c} ; 12$ for 80c; 100 for $\$ 3.00$, postpaid. Ixias-Small plants with clusters of single star shaped. In mixed colors. 6 for 35c; 12 for $60 \mathrm{c} ; 100$ for $\$ 3.00$, postpaid.

WATSONIAS-Spring blooming, resembling the Gladiolus but more graceful. Very fine for indoor decorations. Mixed colors. 3 for $50 \mathrm{c} ; 6$ for $90 \mathrm{c} ; 12$ for $\$ 1.50$. 


\section{Steckler Seed Co. IMPORTANT! Steckler Seed Co. List Remittance Here} INCORPORATED

\section{Seed Growers-Seed Merchants}

New Orleans 3, La.

\section{ORDER BLANK}

Date.

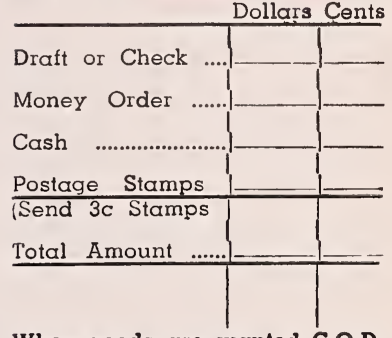

When goods are wanted C.O.D. $25 \%$ of the amount due must accompany the order. No Plants are sent C.O.D.

NOTE: If cash or stamps are For the enclosed $\$$. please send the following order. sent by mail, REGISTER THE

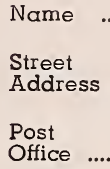

All gardeners of experience know that success with seeds, bulbs and plants depends largely upon weather conditions and proper cultivation. Therefore, Steckler Seed Company, Inc., give no warranty, expressed or implied, as to the productiveness of any seeds, bulbs or plants we sell and we will not be in any way responsible for the crop. Our liability in all instances is limited to the purchase price of the seeds, bulbs or plants.

QUANTITY $\mid$ NAME OF VARIETY




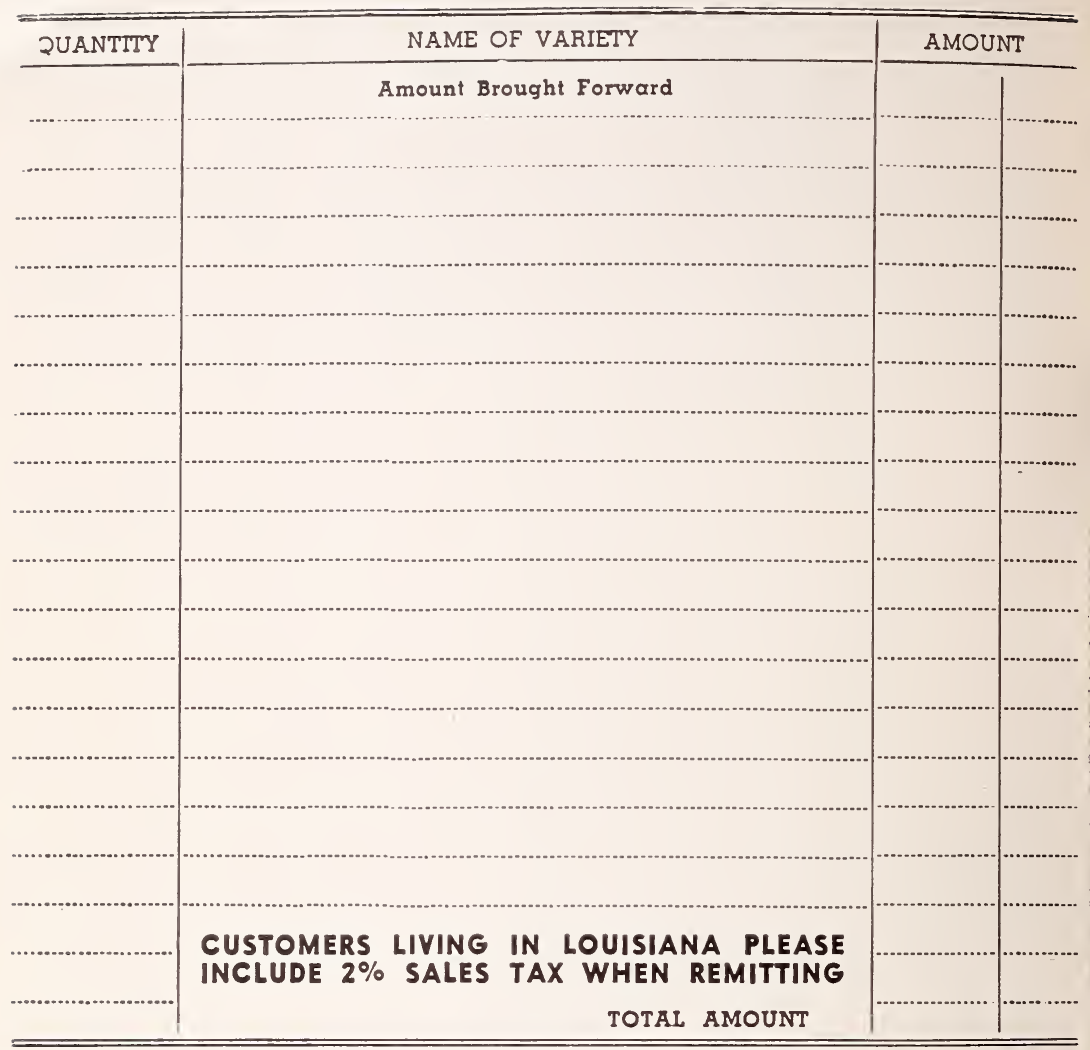

If you know of any farmers, market gardeners or others who are not receiving our catalog, please supply us with their names and addresses. Please use the head of the family only in your list. For your kindness we shall be glad to send you some extra seeds along with your order.
NAME
POST OFFICE
R.F.D. No.
STATE

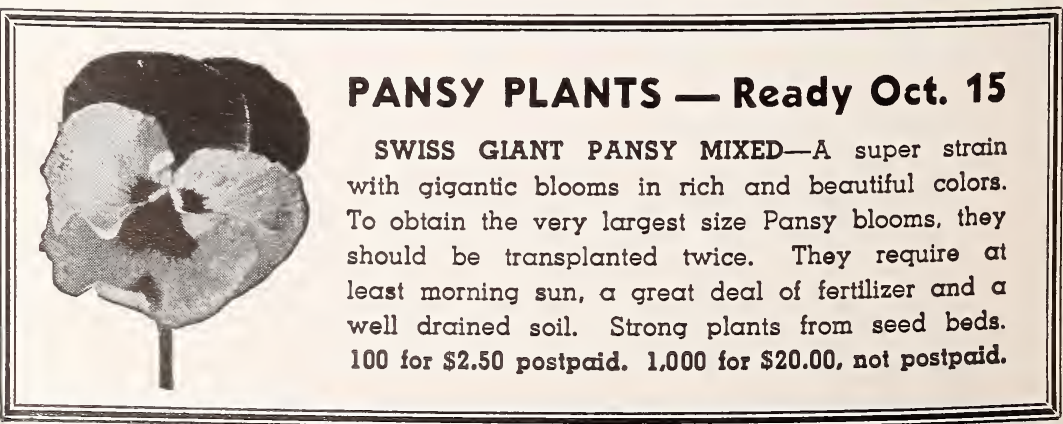




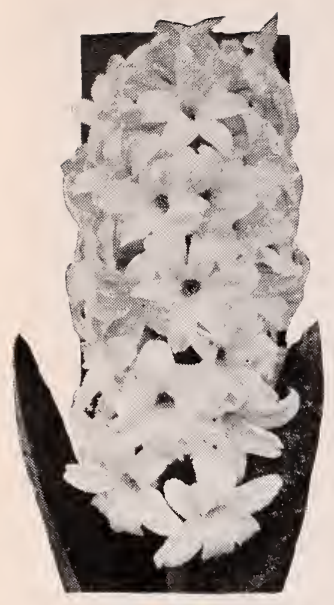

Hyacinth

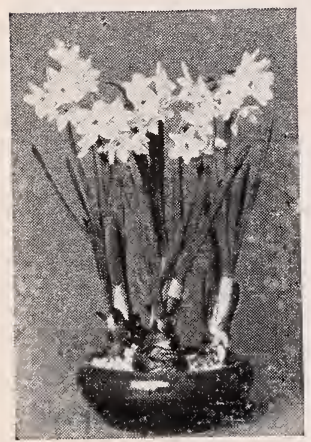

Paper Whites Narcissus

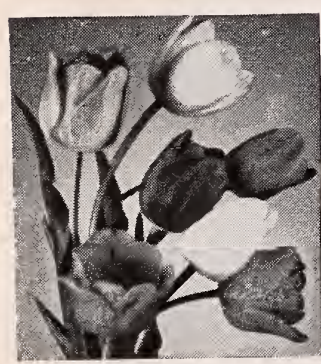

Darwin Tulips

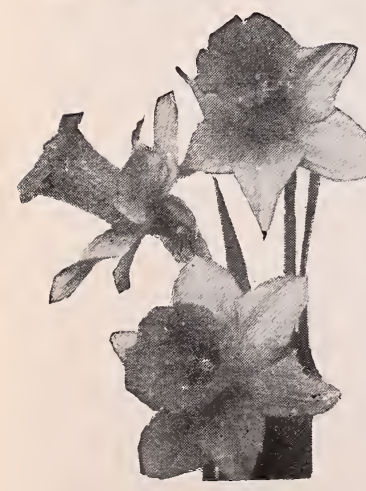

Daffodils

\section{PLANT IN THE PALL}

HYACINTHS-

Culture. Hyacinth bulbs do best in a rich, light, sandy loam with proper drainage. We advise against the use of fresh manure. November and December are our most successful planting months. For outdoor planting, set bulbs 6 to 8 inches apart each way. Cover with 4 inches of soll. Hyacinths are also fine for growing indoors during the winter in pots or pans or in special glasses filled with water.

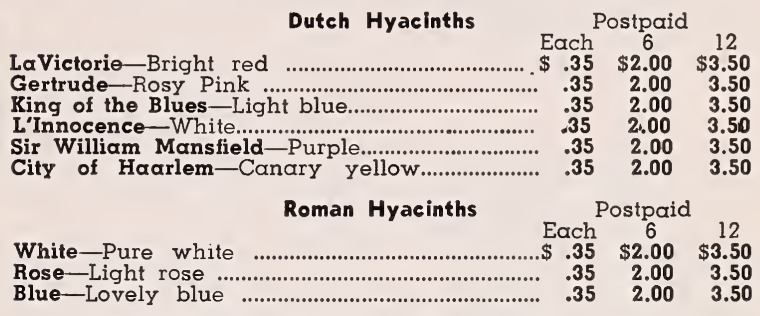

IRIS-There is no trick to growing Iris. They do extremely well in any location, and do well in any garden soil.

\begin{tabular}{|c|c|c|c|c|}
\hline \multicolumn{2}{|l|}{ Dutch Iris } & Postpaid & \\
\hline $\begin{array}{l}\text { Wedgewood-Earliest blue } \\
\text { White Excelsior-Pure White........................ } \\
\text { Yellow Queen-Best of all Yellows...... } \\
\text { lmperator-Brilliant blue, extra early.. } \\
\text { Blue Horizon-Lovely blue, similar to }\end{array}$ & $\begin{array}{l}.35 \\
.35 \\
.35 \\
.35\end{array}$ & $\begin{array}{r}.55 \\
.55 \\
.55 \\
.55\end{array}$ & $\begin{array}{r}\$ 85 \\
.85 \\
.85 \\
.85\end{array}$ & $\begin{array}{r}\$ 5.75 \\
5.75 \\
5.75 \\
5.50\end{array}$ \\
\hline 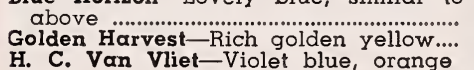 & $\begin{array}{l}.35 \\
.40\end{array}$ & & $\begin{array}{r}.85 \\
1.25\end{array}$ & \\
\hline $\begin{array}{l}\text { blotch } \\
\text { rin. Beatrix-Deep } \\
\text { Vhite Superior-Whit }\end{array}$ & $\begin{array}{l}.40 \\
.35\end{array}$ & .7 & $\begin{array}{r}1.25 \\
.85\end{array}$ & .7 \\
\hline & & & 1.00 & \\
\hline
\end{tabular}

JONQUILS-Highly prized for their delightful fragrance. Splendidly adapted for planting borders and for naturalizing.

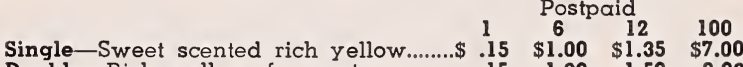
Double-Rich yellow fragrant.................. $\quad .15 \quad \begin{array}{lll}1.00 & \mathbf{1 . 5 0} & \mathbf{8 . 0 0}\end{array}$

\section{Daffodils Postpaid Not pre}

Mrs. R. O. Backhouse-Famous "Pink Daffodil," ivory white perianth, apricot pink trumpet ………….............\$ $.25 \quad \$ 1.35 \quad \$ 2.25 \quad \$ 12.00$

$\begin{array}{llllll}\text { King Alfred-Golden yellow perianth } & & & & & \\ \ldots & & 1.00 & 1.65 & 10.50\end{array}$ $\begin{array}{llllll}\text { and trumpet fringed............................... } & .20 & 1.00 & 1.65 & 10.50\end{array}$

$\begin{array}{lllllll}\text { Beersheba-Best white trumpet } & & & & & & \\ \end{array}$

Mrs. E. H. Krelage-Known as the

$\begin{array}{llllll}\text { White King Alfred................................... } & .25 & 1.35 & 2.25 & 12.00\end{array}$

$\begin{array}{llllll}\text { Carlton-Large yellow Narcissus, } & & & & \\ \text { enormous cup with frilled edges...... } & .25 & 1.35 & 2.25 & 12.00\end{array}$ $\begin{array}{llllll}\begin{array}{l}\text { Unsurpassable - Nacissus trumpet, } \\ \text { extra early, deep golden yellow.... }\end{array} .35 & 1.50 & 2.50 & 15.50\end{array}$

Narcissuss (Indoor or outdoor blooming)

$\begin{array}{llllll}\text { Paper Whites-Pure white, fragrant } & & & & \\ \text { beautifully formed flowers.................... } & .15 & .80 & 1.35 & 7.50\end{array}$

Grand Soleil d'Or-Yellow paper

$\begin{array}{llll}.15 & .85 & 1.25 & 8.00\end{array}$

$\begin{array}{llllll}\text { white } & 15 & 85 & 1.25 & 8.00\end{array}$

\section{DARWIN TULIPS}

Culture. In the South, Tulips should not be planted unti? November or December, when the weather and soll are more uniformly cool. Plant 5 to 6 inches deep, 6 inches apart. Use bonemeal as a fertilizer.

\section{Darwin Tullps}

Blue Amiable-Bright violet purple shaded steel blue, large..

Clara Butt-Salmon rosy pink

Farncombe Sanders-Fiery Rose scarlet with white center.....................................

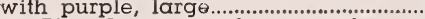
Wm. Pitt-Glowing salmon scarlet........ Yellow Giant-Deepest yellow.................. Zwanenburg-Pure white

Queen of the Night-Purple-black...........

Darwin Mixed-Large blooms, superb mixture
$3 \begin{gathered}\text { Postpaid } \\ 6\end{gathered} 12$ pat Pre- 100

$\begin{array}{rrrr}\$ .45 & \$ .80 & \$ 1.25 & \$ 7.50 \\ .40 & .70 & 1.00 & 6.50 \\ .40 & .70 & 1.00 & 6.50 \\ .45 & .80 & 1.25 & 7.50 \\ .45 & .80 & 1.25 & 7.50 \\ .45 & .80 & 1.25 & 7.50 \\ .50 & .95 & 1.50 & 8.00 \\ .45 & .80 & 1.25 & 7.50 \\ .40 & .70 & 1.00 & 6.50\end{array}$




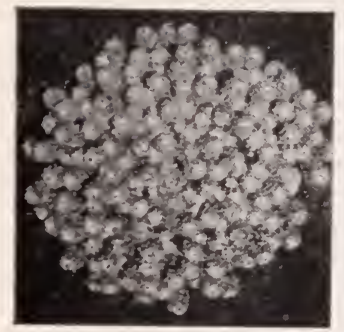

Alyssum, Royal Carpet

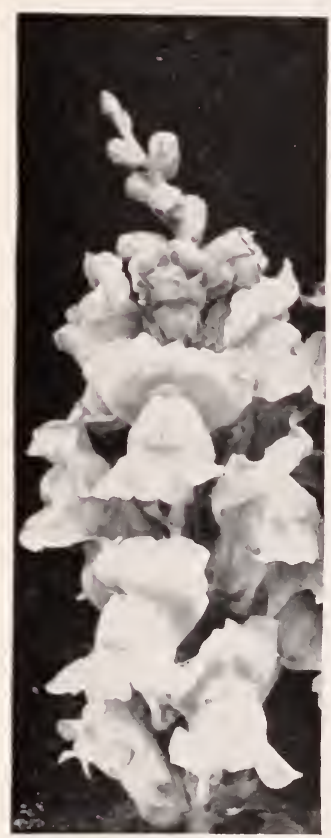

Antirrhinum, Rust Resistant California Giant Mixture

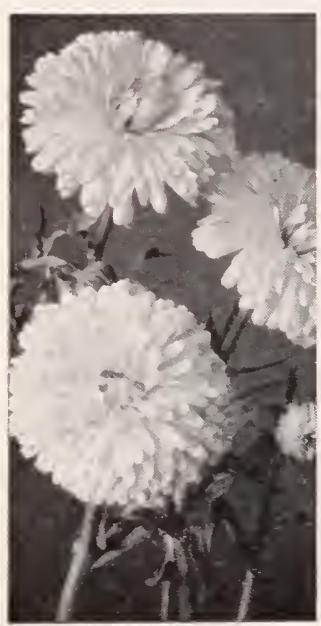

Calondula, Chrysantha

\section{Plant Now for BEAUTIFUL}

Flower seeds are something that everyone is interested in because hidden within their tiny coats are the qualities which after they sprout, and grow, and flower, reveal colorings and characteristics almost unbelievable.

There is no excuse for your not having some flowers around your house when it just takes a few packets of seed, sunshine and rain to have them in all their beauty.

Our seeds are tested and sent to you in big full-measure packets. The instructions are on every packet for planting each kind of seed.

ALYSSUM (Madwort)-Splendid little annual for edging and bedding. Sow July-November. Height 6 to 9 inches.

Little Gem-Dwarf, compact grower thickly covered with small white flowers. Pkt. 15c; oz. $\$ 1.50$.

Violet Queen-Similar to Little Gem, but carries an abundance of delicate, lilac-colored blooms. Pkt. 20c; $1 / 2$ oz.
$\$ 1.00$.

Royal Carpet-New rich violet purple, compact and spreading. Pkt. $25 \mathrm{c} ; 1 / 4$ oz. $\$ 1.75$.

Saxatile Compactum (Gold Dust). Golden yellow, grows to about 12 inches. Pkt. 20c; $1 / 4$ oz. $65 \mathrm{c}$.

ANTIRRHINUM (Snapdragon)-For exquisite beauty few flowers equal the modern Snapdragons. They make glorious massed beds and borders, and are extremely well adopted for cutting. Sow August-November. Height 2 to 3 feet.

Crimson Kinq-Rich crimson, semt-tall sort. Very good for bedding. Pkt. $25 \mathrm{c}$; $1 / 4$ oz. $\$ 1.25$.

Canary Bird-A very fine variety of giant yellow blooms. Pkt. 25c; $1 / 4$ oz. $\$ 1.25$.

Loveliness-Rose pink, giant flowered. Pkt. 25c; 1/4 oz. \$1.25. Shasta-Pure snow-white blooms. Tall, large flowering. Pkt. $25 \mathrm{c} ; 1 / 4$ oz. $\$ 1.25$.

Rust Resistant California Giant Mixture-This mixture of rust proof Snapdragons is the best all around type, equally fine for borders or for cutting. Pkt. $25 \mathrm{c} ; 1 / 4$ oz. \$1.00.

AQUILEGIA (Columbine)-Long-spurred Hybrid Mixed. Few perennials rival the Aqullegia with their odd-shape flowers. Prefer partly shaded location. Sow during October-November. Height $21 / 2$ feet. Pkt. $25 \mathrm{c}$.

ARMERIA (Thrift, Sea Pink)-Dwarf-growing perennials with grassy leaves and a tufted habit of growth. The flowers are borne in alobular heads during March to May, and the plants are suitable for edgings to borders. Pkt. 15c.

BALSAM (Lady-Slipper)-Greatly Improvedl strain, with large, waxy, camelia-like blooms in soft and brilliant shades and combinations. Sow the seed during July and August in a well-drained soil. Delight in a sunny location. Height 2 feet.

Mixed-Improved. Camella-flowered. Very double and beautiful colors. Pkt. 10c; oz. \$1.60.

Bush Flora Alba-Pure white flowers, used for bouquets. Pkt. 25c.

BELL OF IRELAND (Irish Green Bell flowers). Graceful $2 \mathrm{ft}$. branching stems are so surrounded by 2 in. flowers there is little room for leaves. The bell shaped calyx of the flower is green and delicately veined containing the white corolla. Both curious and beautiful. Planted Jan. to May. Pkt. 35c; $1 / 2$ oz. $\$ 1.50$.

CALENDULA-One of our most desirable fall flowers. They are of easy culture, very prolific bloomers, and produce a splendid effect in beds and massed borders. Highly prized as cut flowers. Sow August-October. Height 1 to $11 / 2$ feet.

Radio-Distinct from any other Calendula. The petals are large and double flowers instead of being flat, forming almost a globe shaped flover. It is rich golden orange in color, blooms freely. Pkt. 15c; oz. \$1.25.

The Ball-It has fine stems. immense double flowers of brilliant glistening orange. Great favorite. Pkt. 15c; oz. \$1.25.

Orange King-Outer petals are slightly imbricated, while those of the center are curved like those of a peony. Color glowing orange. Pkt. $15 \mathrm{c}$; oz. \$1.25.

Sensation-Vigorous growth, flowers borne on stout stems blnoms are flat, brilliant orange with $r$ scarlet sheen and full yellow center. Pkt. 15c; oz. \$1.25.

Lemon Ball-Sulphur yellow, double blooming. Pkt. 15c; oz. $\$ 1.25$.

Chrysantha-Large double buttercup yellow flowers, flowers incurved, extremely popular. Pkt. 15c; oz. \$1.25.

Orange Shaggy-New orange colored Calendula, grows 18 inches high. Pkt. 15c; oz. \$1.60.

COREOPSIS LANCEOLATA-Iarge flowered, golden yellow, splendid cut flowers. Pkt. 15c; oz. \$1.25. 
CANDYTUFT-These delightful annuals may be grown with splendid success in fall. They furnish your beds and borders with masses of colors, and are highly prized for cutting. Sow September-November. Height 1 foot.

Coronaria-Hyacinth flowered white. $A$ very fine variety.

Pkt. 10c; oz. $\$ 1.35$.

Umbellata-White. Pkt. 15c; oz. \$1.35.

Umbellata-Pink. Pkt. 15c; oz. $\$ 1.35$.

Umbellata-Crimson. Pkt. 15c; oz. \$1.35.

Umbellata-Rose Cardinal. Pkt. 15c; oz. \$1.35.

Umbellata-Purple. Pkt. 15c; oz. \$1.35.

Mixed All Colors-Pkt. 15c; oz. \$1.35.

CANTERBURY BELLS-These old-fashioned favorites are much admired for their beautiful, large, bell-shaped flowers in shades of white, rose, and blue. Very showy in mixed borders. Sow during October-November. Height 2 feet. Single Annual Mixed-Pkt. 25c.

CARNATION-Few flowers surpass in beauty of form or delicious fragrance the richly hued Carnation. Easily grown from seed, and will produce fine, large blooms if planted in good, rich, well-cultivated soil. Sow during October-November. Height 15 inches.

Dianthus Caryophyllus Margaritae Robustus-Fl. pl. Semi High Double Margaret Carnation. Dwarfish habit. Pkt. 20c; oz. \$2.75.

Cosmos-Delightful annuals with ornamental, feathery, fresh green foliage and large, artistic flowers produced freely throughout the season. Effective as a background for borders and excellent for cutting. Sow during August and September. Height 4 feet.

Bipannata Hybrida-Mixed. A very showy annual similar in shape to the Bright Eye Daisy or Coreopsis, but taller and more brilliant in color. Pkt. 10c; oz. \$1.50.

Early Double-Forms a perfect bush, bearing attractive double flowers of good size on long stems, making a wonderful cut flower. Pkt. 20c.

Early Klondyke Orange Flare-Long stemmed bright orange blooms. Early and long blooming. Pkt. 15c; oz. \$1.50.

Sensation Finest Mixed-Mammoth size flowers, 4 to 5 inches in diameter, with broad, heavy fluted petals carried on very long strong stems. Pkt. 15c; oz. \$1.50

Sensation Kadiance (new)-A striking new color combination never before seen in Sensation Cosmos. Deep rose petals overlaid with large well defined zone of rich crimson. Pkt. $15 \mathrm{c} ;$ oz. \$1.65.

Fiesta-Makes a compact $21 / 2 \mathrm{ft}$. plant with a riot of blooms all summer, blooms are semi-double and ruffled. $\mathbb{A}$ very desirous cutflower for the house. Pkt. 25c.

CYNOGLOSSUM (Amabile)-Also called the "Chinese ForgetMe-Not." A splendid annual of upright bushy growth, producing small single flowers resembling very much a ForgetMe-Not in shape and color.

Blue-A lively plant producing sprays of brilliant blue Forget-Me-Not-like flowers. Grows easily and blooms for a long season. 18 to 24 inches high. Pkt. 10c; oz. $\$ 1.00$.

Pink-Similar to above, but bearing lovely pink blossoms. Sold Out.

CORNFLOWER (Ragged Robin)-Old fashioned garden favorite. Show to best advantages when massed.

Double Mixed-Pkt. 10c; oz. \$1.10.

BELLIS PERENNIS-Finest double mixed variety; 4 inches high. October till January. Pkt. 25c.

DAISY SHASTA (Alaska)-Highly improved strain with very large and broad overlapping petals of the purest white color. Pkt. $15 \mathrm{c} ; 1 / 2$ oz. $\$ 1.00$.

DIANTHUS or PINKS-This group embraces some of our most beautiful and best-loved flowers for bedding and borders. They are unsurpassed for striking colors and profuse blooming. The fragrant, often delicately fringed flowers are of fine velvety texture. Do best in a sunny location. Sow JulyNovember. Height 1 foot.

Chinensis-Chinese Pink. Single. A beautiful class of annuals of various colors which flower very profusely in early Spring and Summer. Pkt. 10c; oz. $\$ 1.50$.

Heddewiggii-Japan Pink. Double. This is the most showy of any of the annual pinks. The flowers are very large and of brilliant colors. Pkt. 15c; oz. $\$ 2.25$.

GAILLARDIA (Blanket Flower)-Mixed. Planted in early spring and will continue to bloom from early summer to November. excellent for beds, borders or for cutting. Pkt, 15c; oz. \$1.35.

GLOBE AMARANTH (Bachelor's Button)-A distinct and showy everlasting flower with pretty, small, clover-like blossoms in purplish red, pink, and white shades. Splendid for massing in beds and borders. Sow July and August. Height 2 feet. Pkt. 10c; oz. $\$ 1.50$.

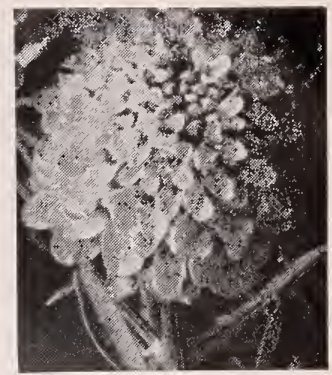

Candytuft, Umbellata
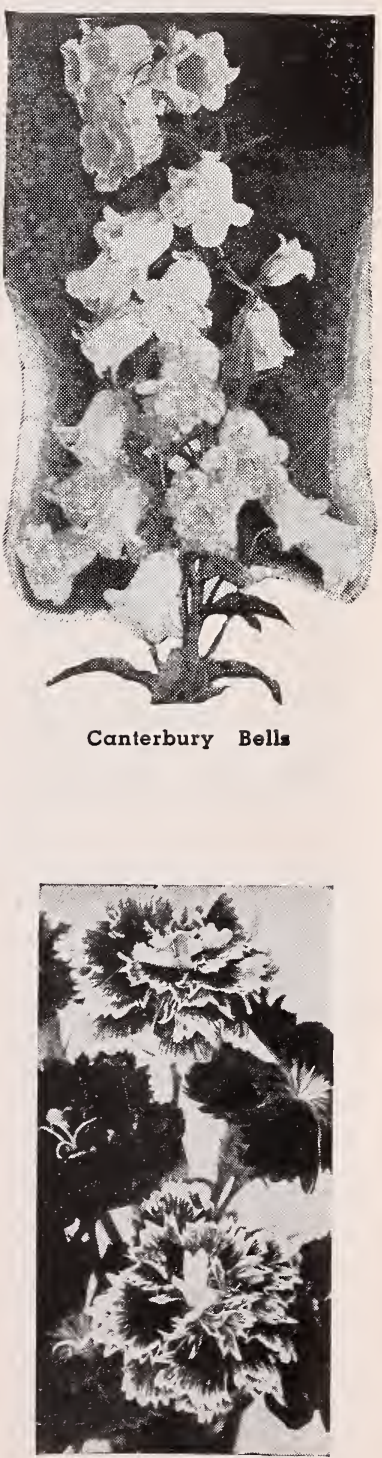

Dianthus or Pinks 


\section{MANY NEW AND SPECIAL VARIETIES}

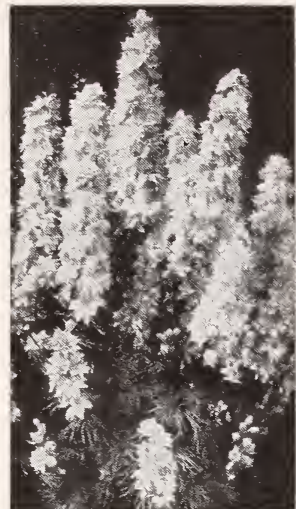

Larkspur, Giant Imperial

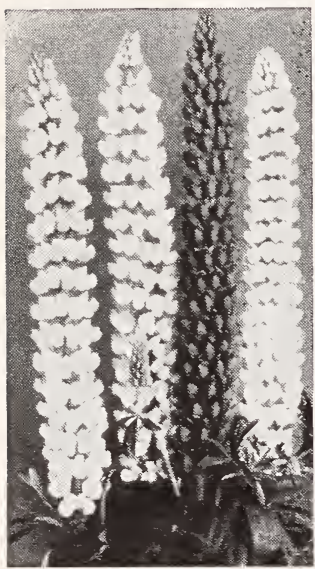

Lupins

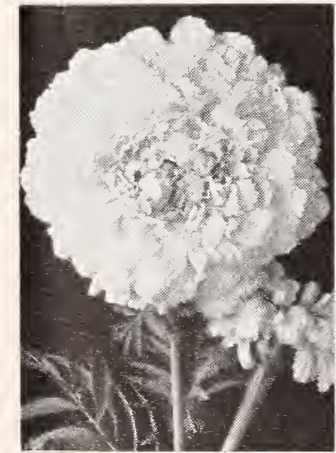

Marigold, Gigantea Sunset Gients
GYPSOPHIL A (Baby's Breath)-Easy to grow annuals of ex. tremely delicate and fairy-like growth. Greatly admired for their myriads of small, dainty, star-shaped blooms, forming a charming misty effect. Fine bed and border plants, and indispensable for combining with other cut-flowers. Sow during September, October and November. Height $11 / 2$ foet.

White-Pure white. Pkt. 10c; oz. \$1.50.

Pink-A very soft pink. Plt. 20c.

HOLLYHOCK-Unequalled as a background for other flowers, plunting among shrubbery, or against houses, fences, or the like. Sow during October-November. Height 5 to 7 feet. Mixed Annual. Pkt. 15c; oz. \$2.50.

LARKSPURS (Annual Delphiniums)-With their finely cut foliage and tall, graceful, floral spikes of double blossoms. Larkspurs provide beautiful, stately backgrounds for mixed borders, and are also wonderful for planting in large, solid beds. Thrive well in almost any well-drained soil but prefer a sunny location. Sow during October-November for early spring blooming.

Double flowered (Height $31 / 2$ feet)

White-Double showy white flowers, borne on long stems. Pkt. 15c; oz. \$1.50.

Dark Blue-Annual, long erect spikes of dark blue, becutiful blossoms. Pkt. 15c; oz. \$1.50.

Bright Carmine-Long erect spikes of fiery carmine flowers, very lovely and effective. Pkt. 10c; oz. $\$ 1.50$.

Rose King-Very attractive spikes in pink blooms. Pkt. 15c; oz. $\$ 1.50$.

Miss California-Rich deep pink on salmon ground, very long sterns and exceptionally long row of flowers. Pkt. 15c.

Giant Imperial-Mixed colors; very showy. Pkt. 15c; oz. \$1.50.

LOBELIA (Erinum)-Lobelia. A very graceful plant with white and blue flowers. Half foot. October till March. Pkt. 25c; $1 / 2$ oz. $\$ 2.00$.

LUPINS-Few flowers give such a glorious display in the garden as Lupins. They are very prolific bloomers and carry graceful, long-stemmed, pea-shaped flower-spikes in delightful shades of white, rose, and blue. Sow September, October and November Height $11 / 2$ feet.

Mixed-Free flowering, easily grown annual. Pkt. 15c; oz. S1.35.

White-Same as above, pure white flowers. Pkt. 15c; oz. SI.35.

Blue-Same as above but blue flowers. Pkt. 15c; oz. $\$ 1.35$. Roseus-Rose colored flowers, long stems. Pkt. 25c; oz. \$1.50.

MARIGOLD-These well-known, hardy, free fiowering annuals enjoy a well-deserved popularity. The African group averages 3 feet in height and has uniformly large, densely double flowers in yellow and orange shades. The French type is dwarf in growth, more bushy, and with striped flowers in yellow and bronze shades. Both are excellent for beds and borders and bloom profusely. Sow July to October.

Tagetes Erecta-African or Tall Growing Marigold. Very showy annual for borders with bright yellow flowers. Two and a half feet high. Pkt. 15c; oz. \$2.00.

Tagetes Patula-French or Dwarf Marigold. Covered with vellow and brown flowers. One and a half feet high. Pkt. $15 \mathrm{c} ;$ oz. $\$ 2.00$.

Dixie Sunshine-Large ball-shaped flowers composed of dozens of tiny five petaled florets, gracefully interlocking, daintily fringed in effect. Brilliant golden yellow. Pkt. 15c.

Tall African All Double Yellow-Exactly the same as the Tall African Marigold in size, but a lovely yellow color. Pkt. 15c; oz. $\$ 2.00$.

Tall African All Double Orange-Exactly like the tall African Marigold in size, deep orange. Pkt. 15c; oz. \$2.00.

Guinea Gold- $\bar{A}$ distinct type growing 2 to $2 \frac{1}{2}$ feet tall, brilliant orange flushed with gold, on early blooming sort, loosely ruffled flowers. Pkt. 20c; oz. \$2.00.

Yellow Supreme-Fluffy well rounded blooms with frilled petals of rich lemon yellow. Is practically free from that objectionable Marigold odor. Pkt. 15c; oz. \$2.00.

Gigantea Sunset Giants-Large flowers, are loosely formed. full centered, with broad heavy petals. Sunset Giants is a mixture ranging from deep orange through golden orange, deep golden yellow, light yellow, lemon yellow and a delightful new shade of primrose. 'Pkt. 15c; oz. \$2.25.

Crown of Gold- $\bar{A}$ gold medal winner for 1937. First known Marigold with odorless foliage. Flower centers are of short curled quilled petals with a collar of flat anard petals on outside. Color is orange; flowers double. Pkt. 15c.

Glitters- $A$ new chrysanthemum flowered African Marigoldgrows about $2 \frac{1}{2}$ to $3 \mathrm{ft}$., bright lemon yellow blooms. Pkt. 25e. 


\section{WE SPECIALIZE IN SEEDS}

NASTURTIUM-Unequaled for easy culture, brilliancy of blooms, and general excellence. Sow during months of September and Ôctober.

Dwarf Mixed-Blossoms red, yellow and salmon, used with leaves as salad. Seed pods while young and succulent picked and used as capers. Pkt. 10c; oz. 45c; $1 / 416$. $\$ 1.25$; lb. $\$ 4.00$.

Tall Mixed-Same as above, makes an excellent screen for unsightly places. Pkt. 10c; oz. 45c; 1/4 lb. \$1.25; 1b. $\$ 4.00$.

Golden Gleam-A double sweet scented Nasturtium, golden yellow blooms with stiff, long stems. This is a distinct and new variety of Nasturtiums and being offered for the first time. Pkt. 10c; oz. 45c; 1/4 lb. \$1.25.

Double Gleam Hybrids-A wide assortment of colors, sweet scented foliage fresh green. Pkt. 10c; oz. 45c; 1/4 lb. \$1.25.

Double Scarlet Gleam-Flowers are fiery orange scarlet and almost three inches across and are uniformly well formed. Plkt. 10c; Oz. 45c; $1 / 4$ lb. $\$ 1.25$.

MATRICARIA (Fever Few)-Double white. A perennial bearing small double white flowers, good for cutting. Pkt. 15c; $1 / 2$ oz. $\$ 1.35$.

NEMOPHILIA INSIGNIS-Blue. Makes a very effective front row to bed or border, also popular for pots. December to April. Plkt. 15c; oz. \$1.10.

GIANT PANSY-The exquisite beauty of the Pansies is well known to every lover of flowers. They are dwarf, compact growers with large, conspicuous blooms of velvety texture in an unusual, striking range of colors and combinations.

Large Trimardeau-Mixed. The flowers are well formed, generally three-spotted, quite distinet; the plants grow compact. October to March. Plet. 25c.

Roggli's Gt.-Mixed. A very early variety of finest and rarest flowers and coloring. Very large blooms and is planted from October to March; grows about 8 inches high. Plat. 50c.

PETUNIA-For freөdom of bloom, variety of color and effectiveness, these annuals have no equal. Extremely hardy, unaffected by heat, drought, or rain. Planted extensively for bedding, bordering and give an excellent display in porch and window boxes. Sow from July to October. Height 1 to 2 feet.

Comanche-Deep torch red blooms, slightly fringed, a little deeper in color than Fire Chief. Price $\$ 1.00 \mathrm{pkg}$.

Dainty Lady-Single Fringed. An entirely new color in $\mathrm{Pe}$ tunias. A delicate golden yellow color. Plants are compact, semi-dwarf and free. Pkt. 75c.

Hybrida-Mixed. Plants are of spreading habit; about 1 foot high. Pkt. 15c; oz. \$3.00.

Rosy Morn-A very pleasing clear pink with a broad white throat. A splendid sort for porch boxes, pots and beds. Grows 1 foot. Pkt. 25c; $1 / 8$ oz. \$1.25.

Giants of California-Mixed. Very large flower and colors embrace every conceivable shade. Pkt. 35c.

Theodosia-Enormous single ruffled flowers of a beautiful shade of rose pink, with golden yellow veined center. Very popular. Pkt. $35 \mathrm{c}$.

Rose of Heaven-Rich, brilliant and effective rose color. Plt. 25c.

Balcony-Mixed. Single lareg flowering, makes an effective display over a long season. Pkt. 25c; $1 / 4$ oz. $\$ 1.00$.

Purple-One of the best rich velvety purple Petunias. Free blooming and compact. Plet. 25c; oz. $\$ 5.00$.

Fire Chief-Brilliant scarlet red. Plants dwarf and compact with long blooming season. Pkt. 50c.

PHLOX-These marvelous annuals flourish in all their glory

throughout the late summer and fall. Particularly attractive in massed beds. Sow July to October.

Perennial Mixed-A mixture from a celebrated collection. Seeds slow in germination. Pkt. 25c.

Drummondi Grandiflora Alba-Pure white, some with purple or violet eyes. Plkt. 25c; 1/4 oz. \$1.25.

Drummondii-Mixed. Their various colors and length of flowering, with easy culture, make them a favorite with everyone. One foot high. April. Pkt. 25c; $1 / 4$ oz. \$1.25.

Fiery Scarlet-Easy culture and a favorite. One foot high. Pkt. 25c; $1 / 4$ oz. $\$ 1.25$.

Flesh Pink-Same as above, but a beautiful shade of pink. Pkt. 25c; $1 / 4$ oz. \$1.25.

Star Mixed-Dwanf-habit, attractive star shaped flowers; a novel variety. Plst. 25c.

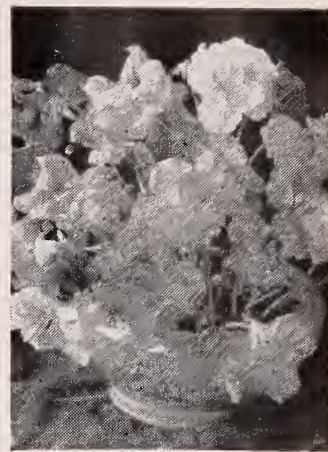

Nasturtiums, Golden Gleam

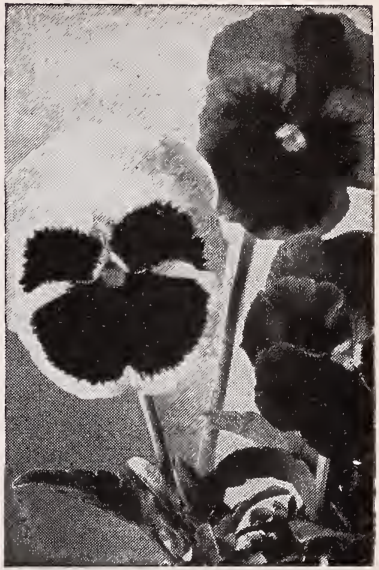

Pansies, Raggli's

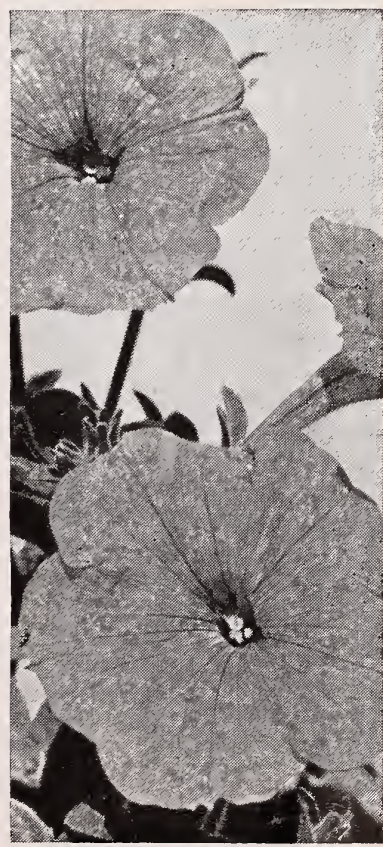

Petunia, Fise Chlof 


\section{THE BEST IN ZINNIAS}

DWARF SWEET PEA MIXTURE - A dwarf grower with large waved flowers. Very popular bedder. Height 1 foot. Pkt. 25c.

SWEET WILLIAM (Dianthus Barbatus)-Free-flowering, hardy biennial for early spring blooming. Sweetly fragrant. Sow September to November. Height $11 / 2$ feet.

Annual Mixed-Pkt. 15c; oz. \$2.00.

TORENIA FOURNIERI-Lovely blue flowers with three large spots of darkest blue and a bright yellow throat. Blooms during summer and fall and makes fine beds and borders. Plkt. 35c.

TITHON1A-Torch-Early, bright orange scarlet with gold center. Plants compact about $3 \mathrm{ft}$. Pkt. $15 \mathrm{c}$.

VIOLA CORNUTA (Tufted Pansles)-Mixed Colors. Produces beautiful, pansy-like blossoms. Ideal for edging or for planting in rock-gardens. Sow August to November. Height 6 inches. Pkt. 25c.

MAMMOTH VERBENAS-Free-flowering, graceful annuals of spreading growth, with glorious, large, umbrella-shaped trusses. Sow July to October. Height $1 \mathrm{ft}$.

White-Pure white verbena of more or less fragrance. One and a half feet high. Pkt. 20c.

Hybrida-Hybridized Verbena. Their long flowering and great diversity of color makes them valuable for every garden however small. All colors mixed. One and a half feet high. Pkt. 15c; oz. \$2.75.

Scarlet-Brilliant scarlet-red flowers of great size, flowers freely during summer. Pkt. 20c.

QUEEN ANNE'S LACE-Hardy annual, large, loosely formed terminal clusters of tiny white flowers, used for cutting. Pkt. 10c; oz. 90c.

VINCA-Free-flowering bedding plants of sturdy, bushy growth, with luxuriant, dark green, glossy leaves and large, single, round, five-petaled flowers in pink and white shades. Sow July to August. Height 2 feet.

Pure White-Pkt. 25c.

Rosea-Rose Pink-Pkt. 25c.

Mixed-Pkt. 25c.

ZINNIAS-Zinnias today claim a prominent place among the preferred annual garden flowers. For fall blooming, sow during July, August and September. In 6 to 7 weeks the plants will begin to bloom; the flowers increase in size and beauty of color as the plants mature. They delight in a sunny location provided with rich soil and abundant moisture.

Blaze Zinnia-All America Winner. Profusion of brilliant mandarin-red flowers changing to fiery orange-scarlet, fluffy, quilled petals, and double. Pkt. 35c.

Giant Dahlia-flowered-Resemble the decorative dahlia because of their unusual depth, open and graceful growth, and curled petals.

Canary Bird-Primrose-yellow.

Crimson Monarch-Crimson-red.

Dream-Distinct deep lavender.

Exquisite-Light rose, darker center.

Oriole-Bright orange and gold.

Polar Bear-Large, pure white.

Prices on above: Pkt. 15c; $1 / 2$ oz. $\$ 1.00$; oz. $\$ 1.65$.

Mixed-A very fine Dahlia-like flower, double, of finest blooms. Pkt. 15c; 1/2 oz. \$1.00; oz. \$1.65.

Lilliput Zinnias-Elegant, small-flowering type with attractive, round, almost globular-shaped blooms resembling the pompon dáhlias. Very prolific bloomer.

Canary-Yellow.

Scarlet Gem-Deep scarlet.

Pink-Deep flesh pink.

White Gem-Pure white.

Prices on above: Pkt. 15c; 1/2 oz. \$1.00; oz. \$1.65.

Pastel Mix-Pkt. 15c; $1 / 2$ oz. $\$ 1.00$.

Fantasy Finest Mixed-Delicate lacy petaled flowers, rounded medium sized with a wide range of beautiful colors, a really beautiful variety. Pkt. 15c; $1 / 2$ oz. $\$ 1.10$.

Fantasy Star Dust-Flowers of medium size, shaggy petaled, color is a rich deep golden yellow, free flowering, early blooming. Pkt. 15c.

Peppermint Stick-New, with a wide range of colors, a good cut and come again Zinnia. Pkt. 15c.

Persian Carpet-Like tiny dahlias with pointed petals, dwart in habit and begins to bloom early. Pkt. 25c.

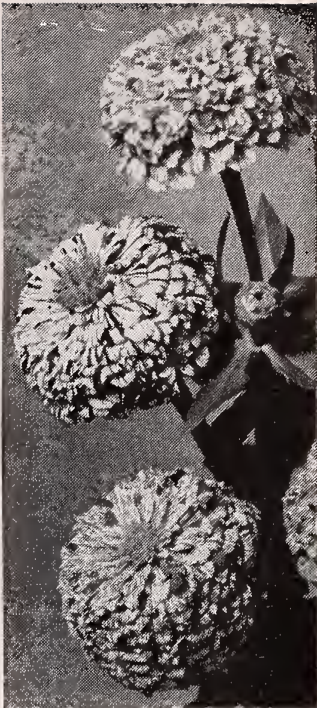

Zinnia, Peppermint Stick

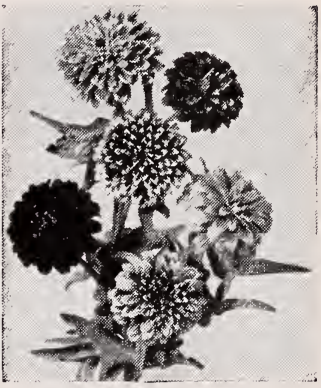

Zinnia, Persian Carpet

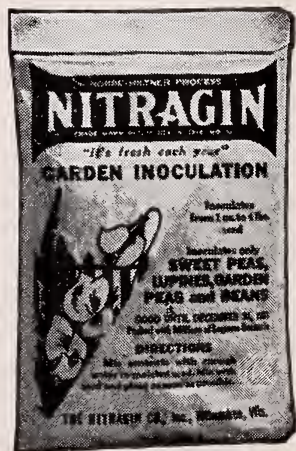

Inoculate Sweet Peas with Nitragin. 25 c Garden size will inoculate 1 ounce. 


\section{RELIABLE SEEDS-TOPS IN QUALITY}

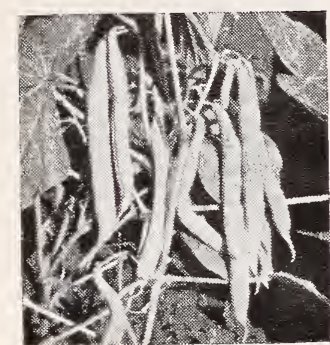

Tendergreen

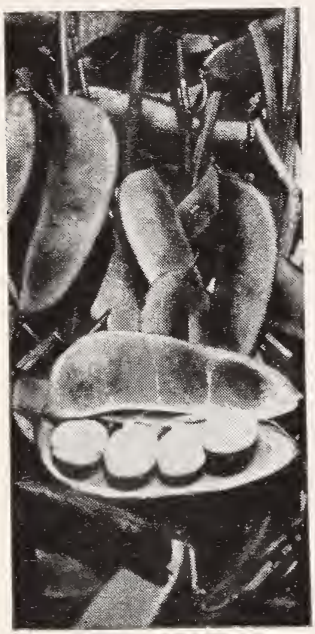

Henderson Baby Lima

\section{Garden Guard}

A non-poisonous Rotenone Dust for killing many sucking and chewing insects. Excellent for controlling Mexican Bean Beetles.

1 lb. can 85c; 4 lb. bag \$1.95, postpaid.

\section{IIITAGT}

\section{BEANS}

String, Wox, Ridney $1 \mathrm{bu}$. each...............60 $\mathrm{c}$

\section{GARDEN SIZE}

Garden Peas and

Beans, Sweet Peas and Iupines

Enough for $6 \mathrm{lbs}$. seod. Retail Price $25 \mathrm{c}$ each.

\section{GARDEN BEANS}

Culture. Plant up to Sept. 20th. Sow $11 / 2$ to 2 inches deep, 3 to 4 inches apart, in rows $2 \frac{1}{2}$ to 3 feet apart. Cultivate often until plants bloom. Picking often insures longer bearing. Two pounds will plant 100 feet of row, $60 \mathrm{lbs}$. (bushel) to the acre.

\section{DWARF OR BUSH GREEN PODDED}

Height of bush 15 to 25 inches. All varieties marketed as green beans except Red Kidney whlch are left to mature.

\begin{tabular}{|c|c|c|c|c|c|}
\hline & & Postpo & & Not F & Pre \\
\hline & $1 / 210$. & & los. & $15 \mathrm{lb}$ & \\
\hline lold type & & $\$ .55$ & $\$ 2.25$ & $\$ 3.25$ & \\
\hline Tal. Stringle & & & & 4.00 & \\
\hline fless & .3 & & & & \\
\hline green & .35 & .6 & & & \\
\hline .......... & .35 & .6 & 2. & 4.45 & \\
\hline ler & & & & & \\
\hline 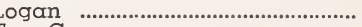 & .3 & .6 & 2. & & \\
\hline & & & 2.6 & & \\
\hline
\end{tabular}

\section{BEANS FOR DRYING}

(10c packets)

Postpaid

Not Prepaid Peck Bu.

Red Kidney $1 / 2 \mathrm{lb}$. Lb. $5 \mathrm{lbs}$. $15 \mathrm{lb}$. $60 \mathrm{lb}$.

\section{BUSH WAX BEANS}

\section{(10c packets)}

Davis Stringless White

Postpaid

Surecrop ........... .35

Improved Golden Wax....................

\section{BUSH LIMA BEANS}

(10c packets)

Postpaid

Not Prepaid Peck Bu.

$1 / 2$ lb 5 Peck Bu.

Henderson Baby Lima ...............35 $\quad .60 \quad 2.50 \quad 4.40 \quad 16.50$

New Calico Bush or Jackson

Wonder

Fordhook 242

$$
.50 \quad 2.35
$$

$\begin{array}{llllll}\text { Bush …............................... } & .35 & .65 & 2.60 & 4.50 & 16.65 \\ \end{array}$

$3.90 \quad 14.75$

\begin{tabular}{|c|}
\hline horogreen \\
\hline
\end{tabular}

\section{SNAP BEANS-POLE OR RUNNING}

\begin{tabular}{|c|c|c|c|c|c|}
\hline \multirow{2}{*}{ (10c packets) } & \multicolumn{3}{|c|}{ Postpaid } & \multicolumn{2}{|c|}{ Not Prepaid } \\
\hline & & & $5 \mathrm{lbs}$. & $15 \mathrm{lb}$. & $\begin{array}{l}\text { Bu. } \\
60 \mathrm{lb}\end{array}$ \\
\hline Wonder or & 35 & .60 & 2.50 & 4.25 & 16.50 \\
\hline 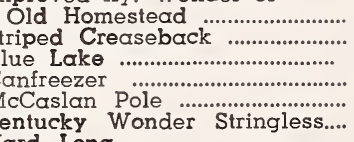 & $\begin{array}{l}.30 \\
.35 \\
.35 \\
.35 \\
.30 \\
.35 \\
70\end{array}$ & $\begin{array}{l}.55 \\
.60 \\
.65 \\
.65 \\
.55 \\
.65\end{array}$ & $\begin{array}{l}2.25 \\
2.50 \\
2.60 \\
2.60 \\
2.50 \\
2.70\end{array}$ & $\begin{array}{l}4.05 \\
4.80 \\
4.95 \\
5.00 \\
4.40 \\
5.50\end{array}$ & $\begin{array}{l}15.50 \\
17.50 \\
18.00 \\
18.50 \\
16.50 \\
20.10\end{array}$ \\
\hline
\end{tabular}

\section{POLE LIMA BEANS}

\section{(10c packets)}

Postpaid

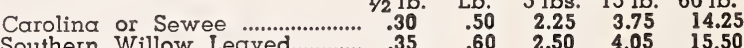
1/2 lb. Lb. 5 lbs. Peck $15 \mathrm{lb}$. $60 \mathrm{lb}$. Spotted Butter or Florida Pole..

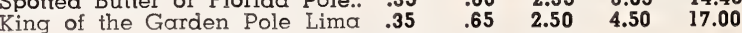

\section{KENTUCKY WONDER POLE WAX}

(10c packets) Postpaid

Not Prepaid

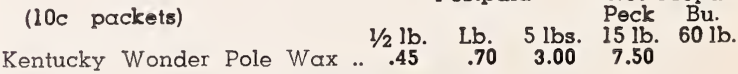

\section{WINDSOR BEANS}

English-Long variety. Edible condition 75 days. Plant two beans every 6 inches and $2 \frac{1}{2}$ feet between rows. Strong upright grower and withstands low temperature. Planted during October and November. Ready to pick during Aprll and May. English-Pkt. 10c; lb. 70c; 5 lbs. $\$ 3.00$; Peck $\$ 5.50$; bushel $\$ 20.00$. 


\section{SEEDS THAT GROW}

\section{GARDEN BEETS}

Culture. Planted from July to October. Rows 18 to 24 inches part Rich sandy loam is preferable, but well fertilized soil will produce fine beets. One ounce to 50 feet of row, 5 to 6 pounds per acre.

(10c packets)

Chicago Early Blood Turnip.

Crosby Early Egyptian

Detroit Dark Red..

Early Wonder

Fireball

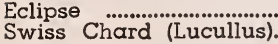

Postpard $\begin{array}{lllll}.25 & \$ & .60 & \$ 1.75 & \$ 7.75\end{array}$

$.25 \quad .60 \quad 1.75 \quad 7.75$

$\begin{array}{llll}.25 & .60 & 1.75 & 7.75\end{array}$

$.25 \quad .60 \quad 1.75$

$.25 \quad .60 \quad 1.75$

$25-60 \quad 1.75$

$.25 \quad .60 \quad 1.75$

\section{STOCK BEETS}

(10c packets)

Long Red Mangel

Klein Wanzleben

Oz. $1 / 4 \mathrm{lb}$. Lid

$\$ \quad .15 \quad \$ .40 \quad \$ 1.25$

$.15 \quad .40 \quad 1.25$

$5 \mathrm{lbs}$

$\$ 5.50$ 5.50

\section{BROCCOLI}

(10c packets)

Oz. $1 / 4 \mathrm{lb}$. Lb.

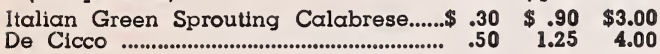

\section{CABBAGE}

Culture. Plantings begin in July and continue all through the fall months for $\alpha$ winter crop. When plants are 4 to 6 inches high transplant. Set the early varieties 18 inches apart in rows $21 / 2$ to 3 feet apart and the late varieties 2 feet apart in $31 / 2$ to 4 foot rows. 1 ounce of seed will produce 1,500 plants; $1 / 2$ pound to the acre.

\section{(10c packets)}

All Head Early

Chinese (Chihli)

Copenhagen Market

Large Late Flat Dutch

Early Drumhead Savoy

Danish Ballhead Short Stem

Mammoth Red Rock

Early Jersey Wakefield

Golden Acre

Chas. Wakefield

Steins Early Flat Dutch

Glory of Enkhuizen

Wisc. All Secton (...............................

Marion Market

Wisc. Hollander No. 8

Ferry's Round Dutch
Postpaid

$\$ \quad .55 \quad \$ 1.50 \quad \$ 4.00$

$\begin{array}{llll}30 & .80 & 2.50 & 12.00\end{array}$

$\begin{array}{llll}.50 & 1.25 & 3.75 & 18.25\end{array}$

$\begin{array}{llll}.45 & 1.15 & 3.50 & 17.00\end{array}$

$\begin{array}{lll}.50 & 1.25 & 3.75\end{array}$

$\begin{array}{lll}.50 & 1.25 & 3.75\end{array}$

$\begin{array}{lll}75 & 1.95 & 6.00\end{array}$

$\begin{array}{lll}.40 & 1.00 & 3.25\end{array}$

$\begin{array}{lll}.50 & 1.25 & 3.75\end{array}$

$\begin{array}{lll}.40 & 1.00 & 3.25\end{array}$

$1.15 \quad 3.50$

$1.00 \quad 3.25$

$1.50 \quad 4.00$

$\begin{array}{ll}1.50 & 4.00\end{array}$

$1.50 \quad 4.00$

$1.15 \quad 3.50$

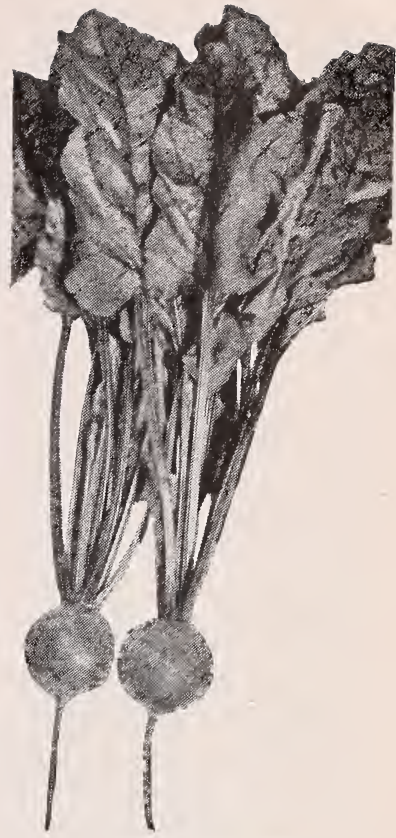

Detroit Dark Red

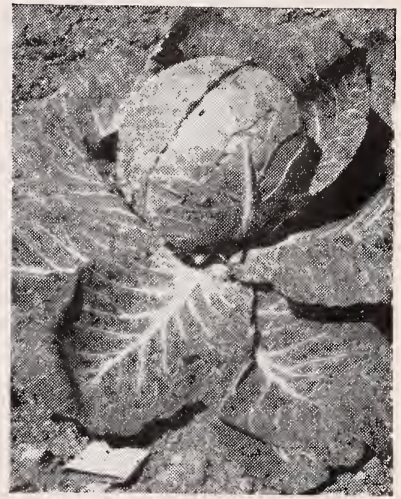

Golden Acre

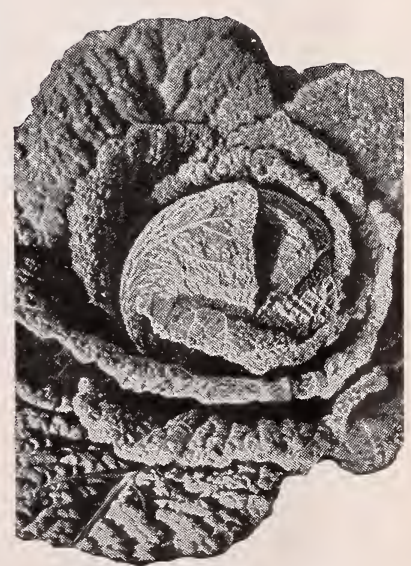

Early Drumbead Savoy

These are strong, open field-grown plants. We ship millions of these frostproof plants direct from our growing stations year after year to satisfied and loyal customers. If you have not tried them, plan to do so this year.

Be sure to mention shipping date on your order. We will ship as near that date as weather at growing station permits. Shipments start about November 1. No order filled for less than 100 plants of the same variety.

Variety: Steins Early Flat Dutch.

100 plonts 1.000 plants

\section{Postpaid Prices}

2500 plants

\section{Not Prepaid}

\section{COLLARDS}

Culture. Planted durng July to September. An old standby tor the South. One ounce will sow 200 feet of row; 6 ounces per acre.

(10c packets)

Oz. Postpaid

Georgia or Southern

$15-\$ 40$. 1.35

Cabbage Collards

$\begin{array}{ll}.40 & 1.35 \\ .45 & 1.35\end{array}$

Louisiana Sweet
$5 \mathrm{lbs}$.

$\$ 3.85$

$\$ 6.25$

6.25 


\section{YOUR COMPLETE GUIDE Steckler llias the Best}

\section{BRUSSELS SPROUTS}

Culture. Planted July to September. 5 ounces per acre.

(15c packets)

Brussels Sprouts

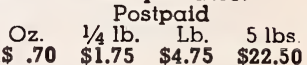

\section{CARROTS}

Culture. Plant during July, August and September. Ground should be well broken, prepared and rich to allow the plant to penetrate. One ounce will sow 100 feet of row, 3 to 4 pounds per acre.

\begin{tabular}{|c|c|c|c|c|}
\hline 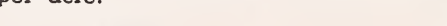 & & Pos & Ingid & \\
\hline ackets! & & $1 / 4 \mathrm{lb}$. & $\mathrm{Lb}$. & \\
\hline Danvers & .35 & $\$ .75$ & $\$ 2.25$ & $\$ 10.00$ \\
\hline Early Half Long Chantenay...................... & .35 & .75 & 2.25 & 10.00 \\
\hline Oxhart & .35 & .75 & 2.25 & 10.00 \\
\hline Imperator & & .85 & 2.50 & 11.25 \\
\hline Improved Long Orange ........................ & .35 & .75 & 2.25 & 10.00 \\
\hline Large White Belgian .................................. & 3 & .75 & 2.25 & 10.00 \\
\hline
\end{tabular}

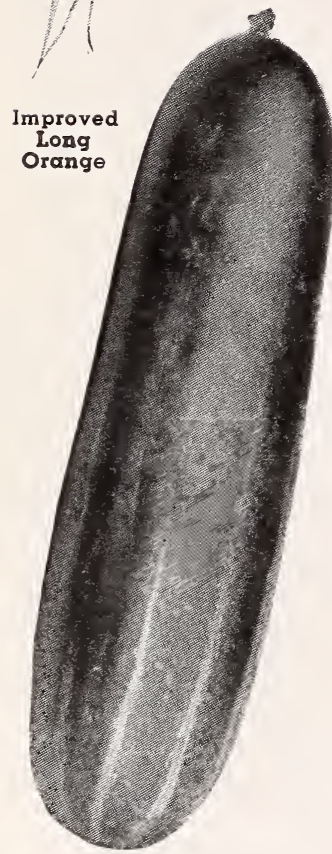

arge White Belgian

\section{CRESS}

(10c packets)

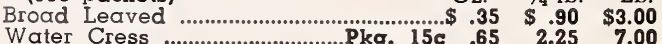

5 lbs.

EGG PLANT

Planted June to August.

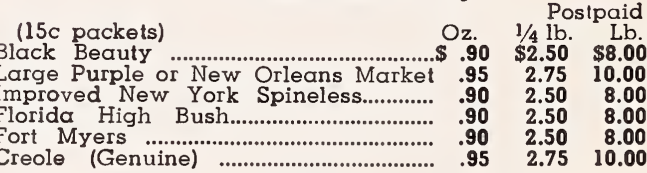

5 lbs.

Improved Long Green

\section{CARDOON}

(20c packets)

Oz. $\quad 1 / 4$ lb. Lostpaid 5 lb. 5 lbs. Cardoon $\$ \quad 60 \$ 1.50 \quad \$ 5.50$

I Ibs.

\section{CHICORY}

(15c packets) Oz. $1 / 4$ lb. Lostpaid 5 Lb. 5 lbs. Chicory or Witloff.

\section{ENDIVE}

Planted September and October.

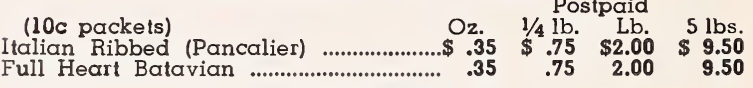

\section{CUCUMBERS}

Planted July to August.

(10c packets) Åshley F-1 Hybrid Superslicer Japanese Climbing ..................................... $\quad .30$ Improved Long Green................................. $\quad \mathbf{. 3 5}$ West Indian Gherkin ................................ $\quad .35$

Staysgreen

Snow or Heinz Pickling.......................... .35

Clark's Special ............................................ .2 .25

Straight Eight

A \& C

Cubit

Palmetto

Marketeer

Palomar-DMR
Postpaid $1 / 4 \mathrm{lb}$. Lb. $5 \mathrm{lbs}$. $\$ 1.00 \$ 3.50$ 75

$\begin{array}{lll}.75 & & \\ .85 & 2.75 & 13.00\end{array}$

.85

$\begin{array}{lll}.65 & 2.00 & 9.00\end{array}$

$\begin{array}{lll}.80 & 2.50 & 12.00\end{array}$

$\begin{array}{lll}.65 & 2.00 & 9.00\end{array}$

$\begin{array}{lll}.80 & 2.50 & 12.00\end{array}$

$\begin{array}{lll}.75 & 2.75 & 13.25\end{array}$

$\begin{array}{lll}.90 & 2.75 & 13.25\end{array}$

$\begin{array}{lll}1.00 & 3.25 & 15.00\end{array}$

$\begin{array}{lll}.90 & 2.85 & 14.00\end{array}$

\section{CAULIFLOWER}

Culture. Planted July, August and September. Requires rich soil and an abundance of moisture. Cultivated same as cabbage. Heads must be protected from sun to get the white head. One ounce will produce 2,000 plants; $1 / 2$ pound per acre. (25c packets) Oz. 1/4 lb. Lb. $5 \mathrm{lbs}$. Early Italian Giant...............................\$1.95 \$6.00 \$15.00 Late Italian Giant.................................. $1.95 \quad 6.00 \quad 15.00$

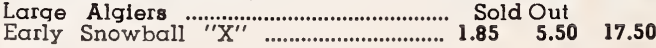




\section{GROW S'TECKLER SBEDS "The South's Best" S'Seeds'}

CORN SALAD

Culture. PJanted during August and September. A hardy winter salad. 2 ounces will plant 100 feet of drill.

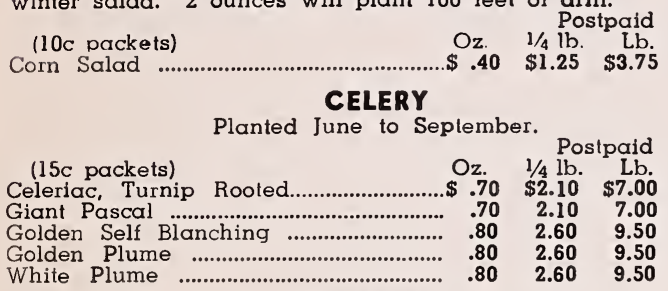

\section{CHERVIL}

Planted October and November.

(10c packets) Oz. $1 / 4 \mathrm{lb}$. Lb. Chervil

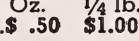

\section{FENNEL}

Planted October and November.

(10c packets) Florence Fennel

\section{KALE OR BORECOLE}

Postpaid Oz. $1 / 4 \mathrm{lb}$. Lb.

\section{Planted August and September.}

Postpaid (10c packets) Dwarf Siberian Oz. $1 / 4 \mathrm{lb}$. $\$ .30 \quad \$ .70 \quad \$ 1.75$

\section{KOHLRABI}

Planted August and September.

(10c packets) Early White Vienna

$$
\text { Oz. } 1 / 4 \text { lb. Lb. }
$$
$\$ .35 \$ .90 \quad \$ 2.95$

$5 \mathrm{lbs}$

\section{LEEK}

Planted October and November.

(20c packets) Large London Flag

Giant Musselburgh$$
\text { Postpaid }
$$

Oz. 1/4 lb. Lb. $5 \mathrm{lbs}$ $\begin{array}{lll}.50 & \$ 1.35 & \$ 4.00\end{array}$ $\begin{array}{lll}.50 & 1.35 & 4.00\end{array}$

$\$ 19.50$ 19.50

\section{LETTUCE}

Culture. Planted from September throughout the fall. $\mathrm{Re}$ quires rich soil, plenty of moisture. When leaves are 2 to 3 inches long, transplant in rows 15 to 18 inches apart and 8 to 10 inches apart in the row. One ounce will sow 150 feet, 2 to 3 pounds per acre.

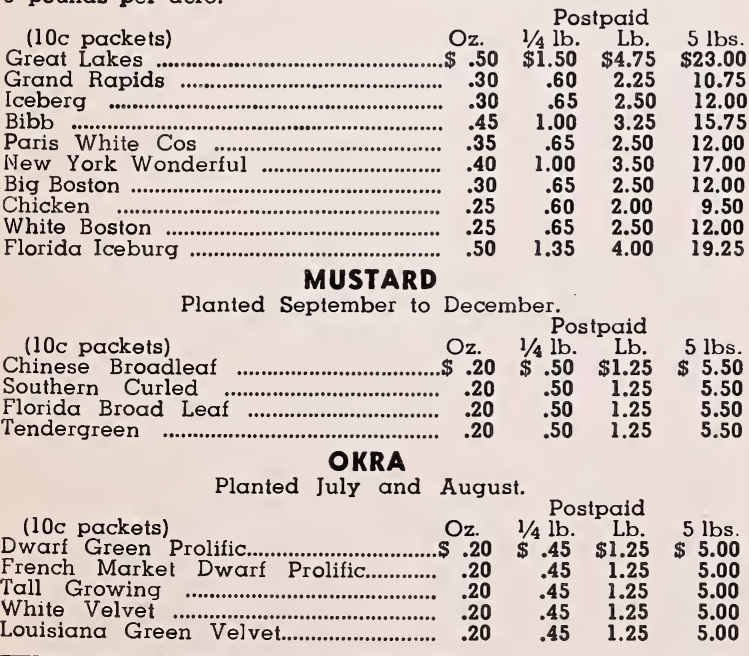

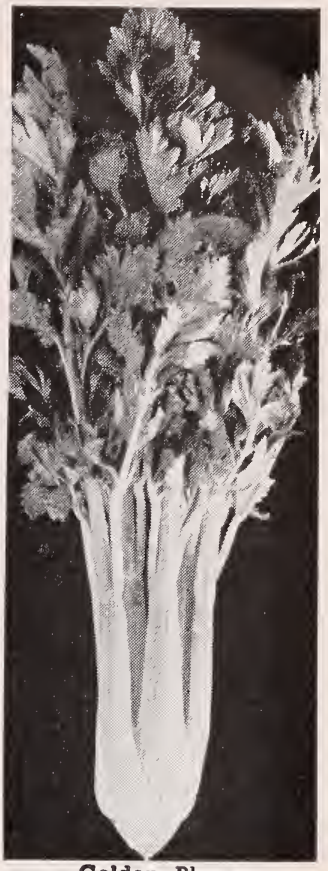

Golden Plume

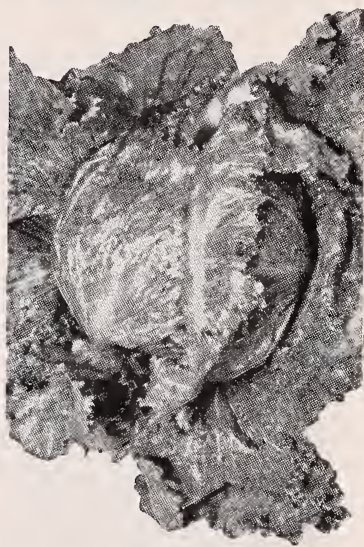

Great Lakes

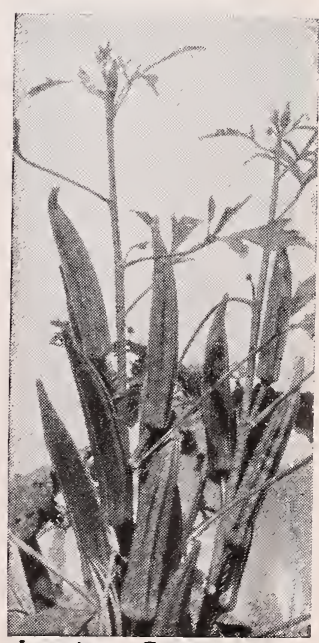




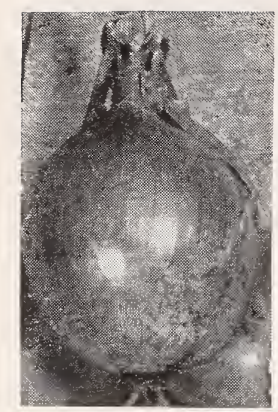

Riverside Sweet Spanish Yellow

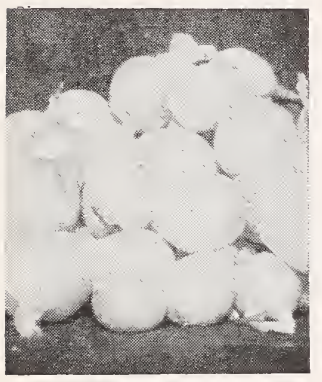

White Silversledn

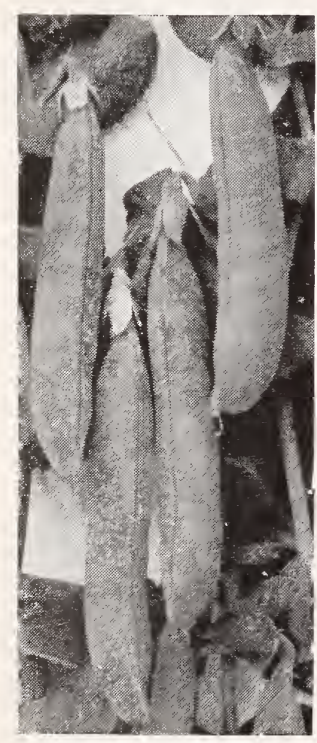

Mammoth Podded Extra Eersly

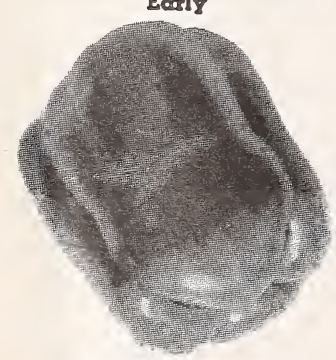

California Wondes

POR EATING PLEASURE

\section{"The South's Best" Seeds'}

ONIONS

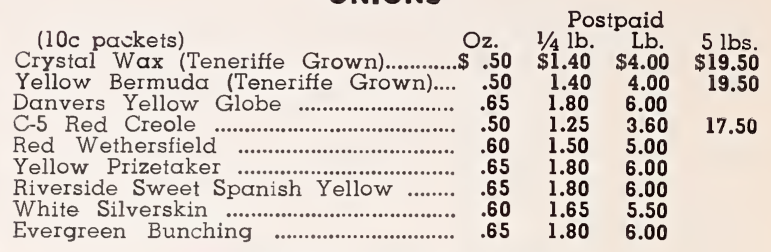

\section{BERMUDA ONION PLANTS}

Sturdy, healthy plants ready to ship about November lst. Grow onions this easy way. You can get much earlier crop of fully matured onions, or early green ontons. Yellow Bermuda and Crystal Wax only.

\section{Write for prices.}

\section{ONION SETS}

Red Wethersfield Postpaid

White Silverskin

Yellow Danvers Write for prices on larger quantities. Lb. $3 \mathrm{lbs}$ $\$ .45 \quad \$ 1.25$ $45 \quad 1.25$

\section{PARSLEY}

Planted August to October.

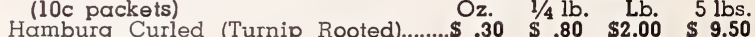

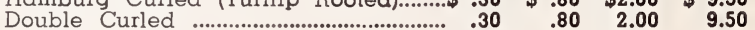

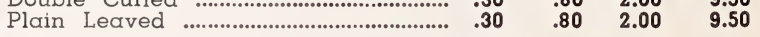

\section{PARSNIPS}

Planted September to November.

(10c packets) Postpaid Hollow Crown or Sugar Oz. $1 / 4 \mathrm{lb}$. Lb. $5 \mathrm{lbs}$.

\section{GARDEN PEAS}

Culture. Planted from August to December. Sow in double rows and the vines will support each other. Rows should be $21 / 2$ to 4 feet apart, and seed planted $11 / 2$ to 2 inches deep, 6 to 8 inches apart. One pound will plant 500 feet of row; $11 / 2$ bu. per acre.

\section{Wrinkled Varietles}

\section{(10c packets)}

American Wonder

Thos.

Carters Imp. Tall

Carters Imp. Tall Telephone...

Crosperity

Little Marvel

Laxton Progress

Smooth Varieties

Early Alasko

Early Washington

Extra Early First and Best......... .30

Mammoth Melting Sugar ……..... .35

Large White Marrowfat ..........

Creole

PEPPERS

Planted July and August.

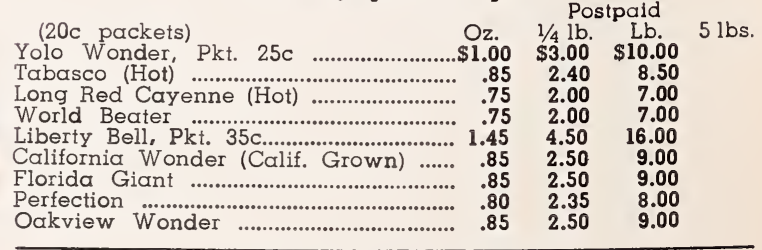




\section{RADISHES}

Plant in August and September.

$\begin{array}{lll}\text { (10c packets) } & \text { Oz. } 1 / 4 \mathrm{lb} \text {. Lostpaid } \\ \text { Bright Scarlet or Three Quarter }\end{array}$

Long

Chinese

Sparkler White Tip

Crimson Giant Turnip.

Crimson Giant Turnip. Turnip.

Early Long Scarlet Short Top Imp........

French Breakfast

White Icicle

Long Black Spanish.

Cincinnati Market

Scarlet Globe

Oz. $\quad 1 / 4 \mathrm{lb}$. Lb.

$\$ .20 \quad \$ .55 \quad \$ 1.25 \quad \$ 5.75$

$\begin{array}{llll}.20 & .55 & 1.25 & 5.75\end{array}$

$\begin{array}{lll}.20 & .55 & 1.25\end{array}$

$\begin{array}{lll}.20 & .55 & 1.25\end{array}$

$\begin{array}{lll}.20 & .55 & 1.25\end{array}$

$\begin{array}{lll}.20 & .55 & 1.25\end{array}$

$.20 \quad .55 \quad 1.25$

$.20 \quad .55 \quad 1.25$

$.20 \quad .55 \quad 1.25$

$\begin{array}{lll}.20 & .55 & 1.25\end{array}$

$.20 \quad .55 \quad 1.25$

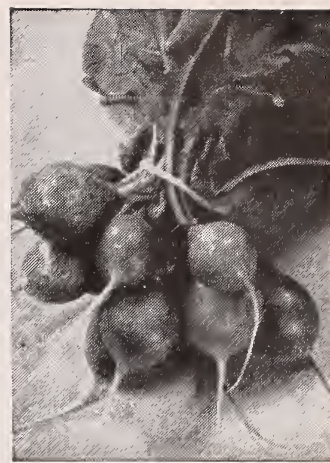

Sccorlet Globe

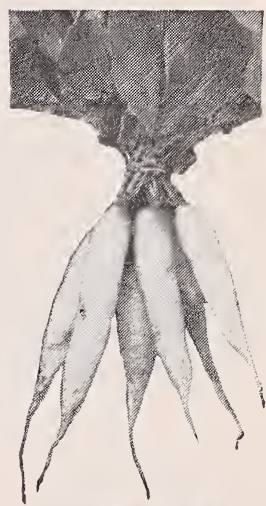

Icicle Radishes

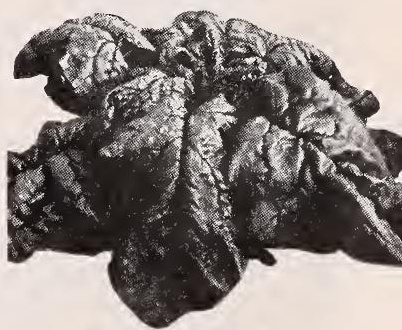

Bloomsdale Savoy



Giant Summer Straight Neck 


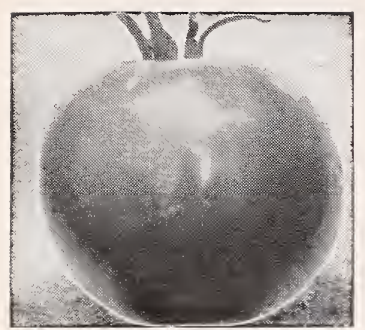

BLOSSOM SET No-Seed Blossom Set is a popular liquid hormone spray for Tomatoes, Strawberries, Cucumbers, and other crops. Makes TO MATOES ripen 1 to 3 weeks earlier, stopping blossom drop. 4 oz. $80 \mathrm{c}$; pt. $\$ 1.85$.

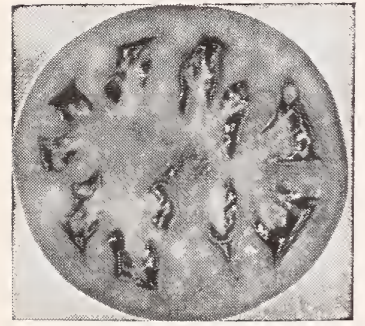

Livingston Globe

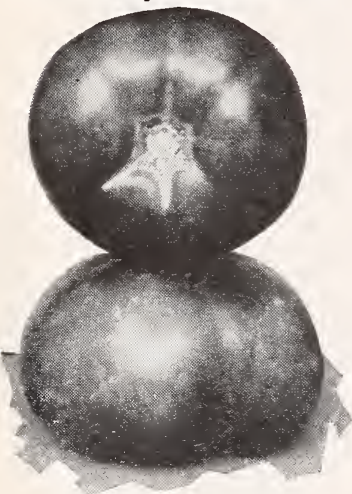

Certified Marglobe

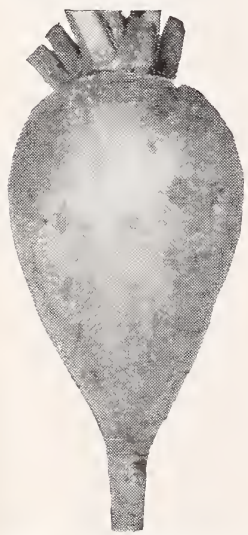

Extra Early White Egg Turnip

\section{CAI TIIE SURPLUS}

TOMATOES

Cuture. Planted during July and August. Soll should be well broken and fertllized. Rows should be 4 to 5 feet apart and the plants set about 3 feet apart in the row or 2 feet if staked. One ounce will produce 1,500 plants, 4 to 6 ounces will furnish sufficient plants for an acte.

\begin{tabular}{|c|c|c|c|}
\hline & & & \\
\hline (15c packets) & & $1 / 4$ & L \\
\hline na & & $\$ 2.50$ & $\$ 8.50$ \\
\hline 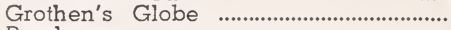 & .8 & 2.50 & 9.00 \\
\hline Ponderosa ........................................... & & 2.0 & \\
\hline $\begin{array}{l}\text { Louisiana } \\
\text { Earliana }\end{array}$ & .05 & $\begin{array}{l}2.5 \\
1.8\end{array}$ & 6.5 \\
\hline 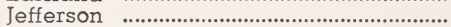 & .75 & 2 & 7.50 \\
\hline (2) & & 2 & 8. \\
\hline Red Oxheart & .1 .00 & 3.5 & 13.2 \\
\hline $\begin{array}{l}\text { Break O Day ..... } \\
\text { Pritchard }\end{array}$ & • $\quad .80$ & $\begin{array}{l}2.50 \\
2.50\end{array}$ & 8.5 \\
\hline Brimmer & 1.00 & 3 & 12. \\
\hline 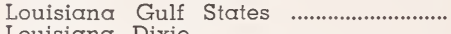 & .85 & 2. & \\
\hline $\begin{array}{l}\text { Louisiand Dixie } \\
\text { Rutgers Certified }\end{array}$ & .8 & 2. & \\
\hline $\begin{array}{l}\text { Rutgers Certified } \\
\text { Dwarf Champion }\end{array}$ & .5 & & \\
\hline Certified Marglobe ...... & .6 & & 7.00 \\
\hline Pear Shaped ................... & .8 & & \\
\hline w $\mathrm{Pe}$ & & & \\
\hline
\end{tabular}

\section{TURNIPS}

Culture. Sow from July to October for fall and winter, in rows 18 inches apart. Plants should be thinned to 4 to 5 inches apart. Can also be sown broadcast. One ounce will sow 200 feet of row; 2 pounds per acre, or if broadcast 4 to 5 pounds per acte.

\begin{tabular}{|c|c|c|c|c|}
\hline & & & & \\
\hline (10c packets) & 0 & & & $5 \mathrm{lbs}$ \\
\hline mber Globe & & $\$ .40$ & $\$ 1.00$ & $\$ 4.50$ \\
\hline Early Purple Top Strap Leaf.. & & .40 & & 0 \\
\hline Extra Early Purple Top Milan.................. & .15 & .40 & 1.4 & 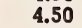 \\
\hline Extra Early White Egg.... & & .40 & 1. & 4.5 \\
\hline Improved Purple Top Rutabaga.. & .15 & .40 & 0 & 0 \\
\hline ng Cow Horn.......... & & .40 & 1. & 0 \\
\hline arple Top White Globe & & .40 & & \\
\hline urple Top Yellow Aberdee & .1 & .40 & 1. & 4.5 \\
\hline n Top ........ & .1 & .40 & 1. & \\
\hline & & .4 & & \\
\hline arly White Flo & .1 & .40 & & 4.50 \\
\hline $\begin{array}{l}\text { urple Top White Glob } \\
\text { Market Gardener's S }\end{array}$ & & 50 & 125 & 5.75 \\
\hline & & & & \\
\hline
\end{tabular}

\section{An excellent assortment of early, medium and late turnips}

1. Extra Early White Egg. 2. Purple Top Strap Leaf. 3. Purple Top Rutabaga. 4. Purple Top Globe. 5. Early White Flat Dutch. 6. Japanese Shogoin. 7. Seren Top.

\section{Varieties_one ounce each $60^{c}$}

\section{CURE YOUR OWN MEATS AT HOME USE}

MORTON'S SUGĀR CURE_-71/2 lb. Can.....................\$1.50

Postpaid $\$ 2.15$

MORTON'S SAUSAGEE SEASONING-10 oz. Can........ 1.20

MORTON'S TENDER QUICK-2 lb. Can....................... 1.10 Postpaid $\$ 1.40$

MORTON'S MEAT PUMP--Postpaid............................ 2.10 


\section{FIELD SEEDS}

\section{for Cassh and Feeding Crops'-..}

\section{for Soil Improvement}

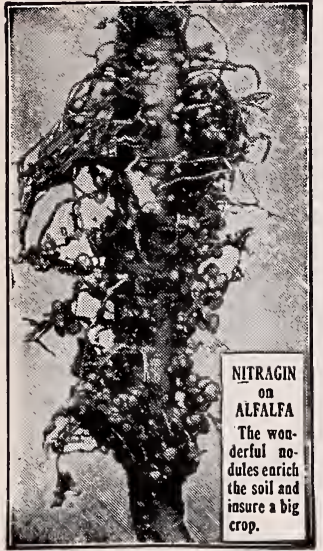

\section{NOTICE}

On account of unsettled market conditions on field seeds, we have not priced any large quantities. Write us for prices. We are large handlers of Vetch, Rye, Grass and $\bar{A}$ ustrian Winter Peas. In fact, field seeds of all kinds. We can save you money.

\section{inOculator PRIeES} When Ordering, Always Specify Name of Seed

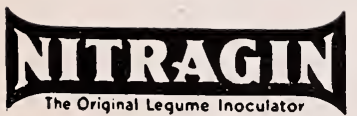

\section{Alfalfa, All Clovers}

Size Retail

100 lbs. .$\$ .70$

Vetch, Austrian Peas, Canadian Peas, Beans

100 lb. size. \$ .55

\section{Lespedeza}

Large (Inoculates up to 100 lbs. seed).......\$ .60
ZOYSIA JAPONICA (Japanese Lawn Grass)-Tough and wear-resistant, immune to diseases and pests, requires only occasional mowing-crowds out Crabgrass. Low growing, sod forming perennial-broad, coarse leaf, if not moved will grow to about 9 inches. Sold Out.

SWEET CLOVER OR MELILOTUS-Also known as Bokhara Clover. As a land-builder it has few equals. It is fine for raising bees and to build up your poor land. Sow 12 pounds per acre in February planting. Lb. 65c; 5 lbs. $\$ 2.75$, postpaid.

YELLOW BLOSSOM SWEET CLOVER-The Yellow Blossom type is very similar to that of the White Blossom. For those who wish to use Sweet Clover for pasture, hay and bee purposes, we would advise the use of the Yellow Blossom type. Lb. 40c; 5 lbs. \$1.35, postpaid. Write for prices on larger quantities.

HAIRY PERUVIAN ALFALFA-Tall, vigorous growing and will live as long as any type where the winters are not too cold and where there is summer moisture. Gives you more cuttings than any other type and after each cutting it recovers rapidly. Sow during September and October in thoroughly prepared, well drained soil, broadcast or in drills at the rate of 15 to 20 pounds per acre. Seed should be inoculated with NITRAGIN. Prices: Lb. $80 \mathrm{c} ; 5$ lbs. $\$ 3.75$, postpaid. Write for prices on larger quantities.

RED CLOVER-Sow in the fall or spring. 12 to $15 \mathrm{lbs}$. to the acre. Largely used in combination with other arasses and clovers for permanent pastures. Prices: Lb. 90c; 5 lbs. $\$ 3.90$, postpaid. Write for prices on larger quentities.

WHITE DUTCH CLOVER-This clover does well in the Central South. Most all permanent lawn and pasture mixtures should have some White Clover. By itself it makes good grazing for cattle and sheep. Lb. $\$ 1.45$, 5 lbs. $\$ 6.50$, postpaid. Write for prices on larger quantitios.

CENTIPEDE GRASS-Low growing, thrives in shade or sun, requires little mowing, grows in rich or poor soil and requires very little fertilizer. Finer in texture than St. Augustine. Sold Out.

FANCY BERMUDA-Most valuable grass for the South. Grows on all kinds of soil heaviest clay to lightest sand and furnishes abundant pasturage. It withstands drought and scorching summer sun. Sow 5 to 10 pounds per acre (2 pounds per 1,000 sq. $\mathrm{ft}$. for lawns). March 1 to September 1 in lower South. Seed will not germinate in cold ground. 20 to 30 days to germinate. Lb. 75 ; 5 lbs. $\$ 2.75$, postpaid.

HULLED BERMUDA-Germinates in a week with proper moisture conditions, almost as quick as Rye Grass. Lb. 95c; 5 lbs. $\$ 3.50$, postpaid.

CARPET GRASS-Carpet Grass is one of the most valuable pasture grasses for the lower South. It grows on poor sandy soils better than Bermuda and does well on most any soil with a fair amount of moisture. Lb. $\$ 1.105$ lbs. $\$ 4.75$, postpaid. New prices in Oct.

FIELD RYE (Ābruzzi)-Lb. 40c; 5 lbs. \$1.75, postpaid.

WHEAT (Atlas 66)-Lb. 40c; 5 lbs. \$1.75, postpaid.

CALIF. BUR CLOVER-The South's greatest cover crop and soil building lequme. Lb. $75 \mathrm{c} ; 5$ lbs. $\$ 2.80$, postpaid. Write for prices on larger quantities.

BARLEY (Bearded)-Lb. 40c; 5 lbs. \$1.75, postpaid. Write for quantity prices.

OATS (Red Rust Proof)-Peck 80c; bu. \$2.60; not prepaid. Write for prices on larger quantities.

RAPE (Dwarf Essex)-Lb. 50c; 5 lbs. \$2.00, postpaid. Write for quantity prices. 


\section{WIITER LAWI GRASS SEED for Beautiful Southern Lawns}

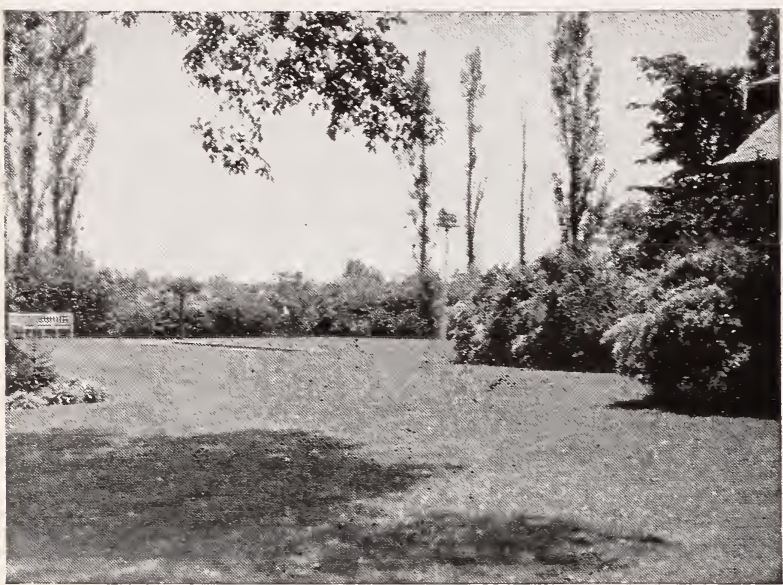

Lawn of Winter Grass

\section{ITALIAN \\ RYE GRASS \\ AMERICAN GROWN}

The winter grass for all the South. Superior to foreign grown ltalian and English Rye Grass seed. Our fancy seed is heavier and more plump. full of vitality, quick to start and strong in growth. It is a fastgrowing annual grass with long flat leaves, growing in tufts if left uncut. It is valuable to dairymen for winter and spring grazing, but its great use is for winter and spring lawns.

Scratch seed in Bermuda sod for green lawn until the Bermuda comes out again in sum. mer. By itself it makes a delightful green lawn, in sun or shade, all fall, winter and spring. If stands repeated mowing on lawn or golf green. Sow $10 \mathrm{lbs}$. per $1,000 \mathrm{sq}$. ft. (50x20 ft.) for lawns; 50 lbs. per acre for pastures. Prices: Lb. 45c; 5 lbs. \$1.50, postpaid. Not Prepaid-10 lbs. $\$ 1.35 ; 25$ lbs. $\$ 3.10 ; 100$ lbs. $\$ 10.50 ; 500$ lbs. $\$ 52.00 ; 1000$ lbs. $\$ 103.00$.

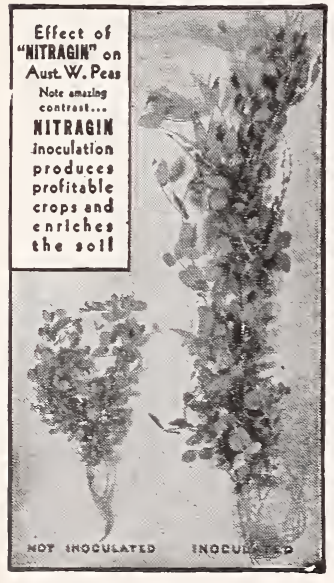

\section{PROTECT YOUR GARDEN}

Against rain, wind, bugs and frost. Use HOTKAPS. Have vegetables and flowers 3 weeks earlier than others.

25 Hotkaps 95c; 100 for $\$ 3.90 ; 250$ for $\$ 7.15$

\section{AUSTRIAN WINTER PEAS DOUBLES YOUR CORN and COTTON YIELDS}

Rapidly climbing to the top as the leading soil-builde: and winter crop throughout the entire South, because of its large, heavy growth on practically all soils and its ability to resist winter freezes. Matures two weeks ahead of Vetch and makes a splendid temporary pasture in late winter. Furnishes grazing for your livestock, and decays rapidly when plowed under.

Sow Austrian Winter Peas during September and October in drills, at the rate of 30 pounds per acre and cover 2 inches. May also be sown broadcast and disked in. Sowing the seed broadcast in cotton middles and straddling the rows with a two-horse cultivator with the disk hillers or plows is a very good method of covering. Lb. $40 \mathrm{c}$; 5 lbs. $\$ 1.25$, postpaid. Not prepaid: $10 \mathrm{lbs} .95 \mathrm{c}$; 25 lbs. $\$ 2.10$; 100 lbs. $\$ 6.45$.

\section{HAIRY VETCH}

\section{An Outstanding and Reliable Soil Builder}

Poor soil can soon be made rich with it. Planted combined with small grain, such as Oats and Rye or seeded alone makes splendid winter and spring pasturage. Stands severe winters without injury, grows on practically all types of soil. Vetch is usually turned under in early April. A good crop is equivalent to 250 pounds or more of Nitrate of Soda and valuable humus is put into the soll. Planted September to December, sow 20 to 25 pounds per acre alone, 15 pounds with small grain. Inoculate with NITRAGIN C. Lb. 45c; 5 lbs. \$1.60, postpaid. Not prepaid: $10 \mathrm{lbs} \$ 1.90 ; 25$ lbs. $\$ 4.35 ; 100$ lbs. $\$ 16.00$.

\section{COMMON VETCH}

Common Vetch prefers sandy loam, well drained, but will produce a good crop on most any other soil where water does not stand. When planted alone it requires 30 to 40 lbs. to the acre, half that quantity is sufficient when sown with small arain. Seed should be inoculater with Nitraain. Lb. $45 \mathrm{c} ; 5$ lbs. $\$ 1.50$, postpaid. Not prepaid, 10 lbs. $\$ 1.35$; 25 lbs. $\$ 2.85 ; 100$ lbs. $\$ 10.25$.

Prices on Larger Quantities on Request 


\section{INSECTICIDES YOU NEED}

ARSENATE OF LEAD-Kills leaf-eating insects. Sticks to foliage. Quick action. Harmless to plants. Lb. $\$ 1.00 ; 4$ lbs. $\$ 2.45$, postpaid.

BOTANO DELUXE GARDEN DUST-For general garden use against many insects and diseases. Dusting is preferred by many, particularly on vegetables. One of the safest multi-purpose dusts that can be used. 10-oz. size is Dual Purpose package which also serves as a handy garden duster. 8-oz. Duster \$1.25. 1-1b. Refill $\$ 1.50$.

BLACK LEAF " 40 "-A 40 per cent Nicotine solution for destroying aphis, thrip, plant lice and sucking insects, also kills poultry lice. One ounce makes six gallons spray. 2 oz. $98 \mathrm{c} ; 6$ oz. $\$ 1.98 ; 12 \mathrm{oz}$. \$2.98; 5 lbs. $\$ 7.90 ; 10$ lbs. $\$ 14.70$.

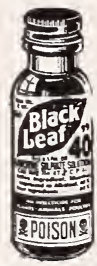

BORDEAUX MIXTURE- $\bar{A}$ standard dry pow dered fungicide for many diseases of orchard and garden plants. Lb. $\$ 1.00 ; 4$ lbs. $\$ 2.25$, postpaid.

BUG-GETA BAIT-Multi-purpose Bait for use against slugs, cutworms, sowbugs, and grasshoppers. Just sprinkle it on the ground. 1 lb. $80 \mathrm{c} ; 2$ lbs. $\$ 1.29 ; 5$ lbs. $\$ 2.50$, postpaid. Not prepaid; 25 lbs. $\$ 8.00$.

LAWN-A-GEN-Ān excellent soil fumigant for controlling Nematodes and other soil parasites. 1 gallon treats 2,500 square feet. 4 oz. $90 \mathrm{c}$; pt. $\$ 2.25$; qt. $\$ 3.40$; gallon S9.75, postpaid

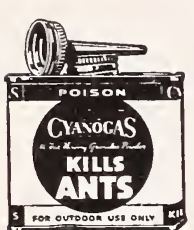

CYANOGAS - This o a producing powder will kill ants, rats, moles, etc. 4 oz. can 55c; lb. can $\$ 1.35 ; 5 \mathrm{lb}$. can $\$ 4.75$, postpaid.

DOGZOFF-Protects your plants from dogs, rats, moles, mice, rabbits etc. Not harmful to plant life. Simply spray on plants. No mixing. 3 oz. bottle $80 \mathrm{c}$ postpaid. 11 oz. Dispenser $\$ 2.25$.

\section{VOLCK OIL AND FLORIDA VOLCK}

For many years the favorite spray of gardeners, use on $\mathrm{Ca}$ melias, Azaleas and Citrus Fruits for scale and red spider.

\begin{tabular}{|c|c|}
\hline Volck Oil & $\mathrm{lg}$ \\
\hline $\begin{array}{rrr}4 & \text { oz. } \quad .40 \\
0 \text { oz. } & .80 \\
\text { oz. } & 1.50 \\
\text { oz. } & 3.19\end{array}$ & $\begin{array}{ll}\text { nt } & \text { s } \\
\text { t. } & 1 \\
\text { al. } & 3\end{array}$ \\
\hline
\end{tabular}

5 gal. 10.50

Not prepaid only on 5 gal. price.

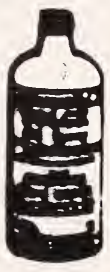

ORTHOCIDE-Garden Fungicide (Contains Captan) for control of Black Spot, Damp Off, Seed Rot, Brown Patch and other diseases of lawns. 8 oz. \$1.49; I lb. \$2.25.

IMPROVED ISOTOX - LONG lasting insect control with Isotox Garden Spray-Kills insects fast and keeps them off plants for weeks. Kills a $\mathrm{ph}$ is, leafhoppers, sod webworm, thrip, caterpillars, red bugs, roaches, ticks, ants and other insect pests. 4 oz. $\$ 1.25 ; 8$ oz. $\$ 2.00$; pint $\$ 3.25$.
EVERGREEN SPRAY-A non-poisonous spray for sucking insects like lice, aphids and thrips. Needs no soap and leaves no poisonous residue. Oz. 40c; 6 oz. \$1.35; 16 oz. \$2.90; q t. $\$ 4.25$.

FERMATE-A new organic fungicide which has shown outstanding results by controlling most fungus diseases. $1 / 2 \mathrm{lb}$. $\$ 1.10$. 3 lbs. $\$ 2.70$, postpaid.

DITHANE Z-78-For use on Azaleas for Petal Blight. Begin spraying when buds begin to appear, 3 applications per week for 3 weeks. $3 \mathrm{lb}$. pkg. $\$ 2.85$, postpaid.

RED ARROW-A concentrated insecticide. Will efficiently control aphis, beetles, caterpillars, as well as other sucking and chewing insects. Non-poisonous. Oz. 50c; 4 ozs. \$1.19; pt. \$3.49.

SABADILLA DUST (20\% Sabadilla)-Controls many hard-to-kill insects like Stink Bug, Squash Bug, Mexican Bean Beetle, etc. Non-poisonous when used as directed. L.b. $\$ 1.00 ; 5$ lbs. $\$ 3.25$, postpaid.

SNAROL-A scientifically prepared meal for the control of zutworms, slugs, snails, earwigs, sow bugs and grasshoppers. Harmless to plants. $1 \mathrm{lb}$. 60c; $21 / 2$ lbs. $\$ 1.10 ; 6$ lbs. $\$ 2.25$, postpaid.

PARATHION $15 \mathrm{~W}-\mathrm{A}$ wettable powder for use on agricultural crops for hard to kill insects such as Red Spider, Mealy Bugs and many species of scale. Use only with extreme caution. $1 \mathrm{lb}$. baq $75 \mathrm{c}$, postpaid.

WETTABLE DUSTING SULPHUR - MaY be used as a dust or spray. Effective against red spiders and fungus diseases such as mildew, rust and black spots. $2 \mathrm{lb}$. can $\$ 1.00$.

TOBACCO DUST-Kills $a p h i d s$ and flea beetles. Extra-fine quality. Contains one per cent nicotine. 5 lbs. 95c; 10 lbs. $\$ 1.50$; postpaid. Not prepaid: 100 lbs. $\$ 7.00$.

\section{ACME DURADUST \#50}

A finely divided, wettable powder containing $50 \%$ technical DDT. Has many uses in control of insects in the garden, on fruit trees and in outbuildings. Kills both sucking and chewing insects on foliage, houseflies and mosquitoes by wall treatment. Most economical form to buy DDT.

1 lb. $\$ 1.10 ; 4$ lbs. $\$ 2.25$, postpaid.

FRUIT TREE SPRAY-Highly effective against many insects and fungus diseases attacking fruit trees.

12 oz. $\$ 1.75 ; 2$ lbs. \$3.55, postpaid.

TREE TANGLEFOOT-Applied to trees, keeps ants and caterpillars from crawling up; a sure cure for most insect troubles on all kinds of trees. 5 oz. $\$ 1.00 ; 1 b$. $\$ 1.65$, postpaid.

GRAFTING WAX - A specially prepared wax to be used for pruning and grafting purposes. $1 / 4 \mathrm{lb}$. 45c; $1 / 2 \mathrm{lb}$. 65c; $1 \mathrm{~b}$. 90c, postpaid.

PRUNING PAINT - $A$ specially prepared paint for treating wounds left by pruning or accidents on trees and shrubs. Pint $60 \mathrm{c} ;$ qt. 90c; gallon $\$ 2.60$, postpaid.

\section{FRUITONE}

The Hormone Spray. Prevents premature drop of flowers, fruit and leaves. $2 / 5 \mathrm{oz}$. $25 \mathrm{c} ; 2$ oz. $\$ 1.00 ; 12$ oz. $\$ 5.00$, postpaid.

\section{TRANSPLANTONE}

Invigorates roots and reduces loss in transplanting seedlings, rose bushes, plants, shrubs and trees. Specially recommended, when transplanting out of season. $1 / 2 \mathrm{oz}$. $25 \mathrm{c} ; 3$ oz. $\$ 1.00$; 1 lb. $\$ 4.00$, postpcid. 


\section{Here today...for your garden}

\section{MELNOR'S NO. 1000 OSCILLATING SPRINKLER}

Sprinkles rectangularly and adjusts to water areas up to 2,400 square feet with just one setting. Never needs oiling and is easily moved without shutting off water. Allows more uniform spray and deeper penetration. One of the finest sprinklers available today. \$12.95.

NO. 700 -Adjusts to water areas up to 2,000 sq. ft. $\$ \mathbf{9 . 9 5}$.

NO. 550 -Adjusts to water areas up to 1,700 sq. ft. $\$ 7.95$.

\section{ARAMITE-15 W}

Most effective miticide. Controls Red Spider and other mites on roses, evergreens, nursery stock, shade trees, easy to use. $4 \mathrm{oz}$. $\$ 1.10 ; 4$ lbs. $\$ 2.95$.

\section{DIELDRIN}

Sensational control of lawn insects and many others in gardens, gardening soil and household. Controls ants, chiggers, white grubs, sod webworms, and others; household pests as roaches, silverfish, carpet beetles and others. 15 oz. $\$ 1.25 ; 3$ lbs. $\$ 2.90$.

\section{DIELDRIN $18 \%$}

Will combat the same insect as $5 \%$ Dieldrin but of higher concentrate and in liquid form. 8 oz. \$1.30; qt. \$3.75; qal. $\$ 11.60$.

\section{SEQUESTRENE NaFe IRON CHELATE}

For correction in iron deficiency in plants. Can be used in foliage spray or applied to the soil.

4 oz. $\$ 1.25$

5 lbs. 3.10
8.60

\section{Postpaid}

TERRA-LITE (Vermiculite Plant Aid) Aids in creating a dependable reservoir of plant root moisture; air-conditions the ground; fluffs stiff soil to prevent cooking, packing and hardening; tends to reduce need for watering and cultivation; provides a satisfactory medium for cuttings, seөdlings and transplantings. Ideal for storing bulbs, particularly dahligs and for vegetable winter storage. Postpaid, 4-quart plkg. 60c; $1 / 2-b u$. bag $\$ 1.25$. Not postpaid, 4-qt. pkg. 40c; $1 / 2-b u$. bag 89c; 2 bu. bag $\$ 1.85$; 3-bu. bag $\$ 2.25$.

\section{"AIRWRAP" AIRLAYERING}

Everything necessary for easy, inexpensive airlayering plant propagation. Ideal for beginner, hobbyist and home gardener. Contains patented Airwrap coated plastic material, plant ties and genuine spaghnum moss as well as de. tailed illustrated instructions anyone can follow. Price $\$ 1.95$ each.

\section{THE TALK OF THE PLANT WORLD} "Gibberellic Acid"

Amazing new growth stimulant for flowers, house plants, etc. Not a fertilizer or hormone. This amazing plant growth booster will actually make plants grow up to three times bigqer than normal.

Wonder-Brel-2 .$\$ .85$

Wonder-Brel-4 oz.

Tablet Form Boostabbs-2. tablets to pack age, sufficient for 1 pint solution, 69c.

\section{MALATHION $50 \%$ Spray}

An entirely new spray for the control of rites, aphids, psylla and white flies. Can be used on fruit trees, vegetable and ornamental plants. 4 oz. $\$ 1.25 ; 8$ oz. $\$ 1.95 ; \mathrm{pt}$. $\$ 3.00$; qt. $\$ 5.50$, postpaid.

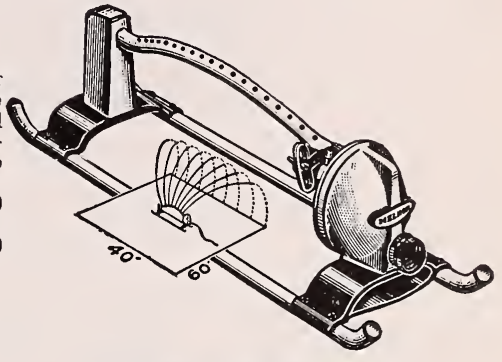

CHLORDANE 10\% Dust

Chlordane is new, powerful and effective in controlling insects 3 ways-by contact when eaten or by inhalation of its vapors. Good for use in the garden and on lawns. Lb. $85 \mathrm{c} ; 4$ lbs. $\$ 2.00$, postpaid.

\section{CHLORDANE Synklor 50-W}

A dry wettable powder. Controls ants, chinch bugs, grasshoppers, Japanese beetles, male crickets, roaches, ticks and wire worms. $1 / 21 \mathrm{~b}$. can $\$ 1.60$; $1 \mathrm{lb}$. can $\$ 2.60$; $5 \mathrm{lb}$. can $\$ 6.15$, postpaid.

ORTHO-KLOR 44 (Chlordane Spray)

For control of ants, lawn moths, cutworms, sowbugs, chinch bugs and other garden pests. Has long residual killing power.

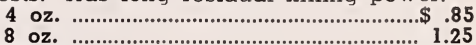

Pint 2.15

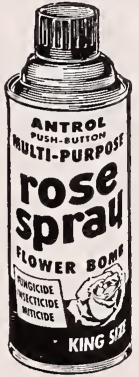

\section{ANTROL MULTI-PURPOSE ROSE SPRAY BOMB}

Works 3 ways-kills insects-kills mites and controls black spots, powdery mildew fungus diseases. 15 oz. bomb $\$ 1.59$.

\section{RIDZ DOG REPELLENT BOMB}

Spray on shrubs, hedges tree trunks, fence posts etc., leaves a protective coat that dogs don't like. Effective against cats also. 12 oz. bomb $\$ 1.49$.


\section{ANTROL AFRICAN VIOLET AND HOUSE} PLANT INSECT BOMB

Kills Mealy Bugs, Mites, Aphids, exposed Thrip White Flies. Specifically for use on African Violets. 6 oz. bomb 89c. 


\section{A FEW OF OUR GARDEN SUPPLIES}

Descriptive Catalog on Request

A complete kit for testing contents of nitrogen, phosphate, potash, and acidity of the soil. This is a valuable aid for the farmer and

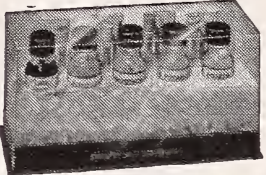
home-gardener. Home Model (makes 20 tests), \$3.98. Club Model (makes 50 tests), \$6.98; Horticultural Model (makes 150 tests), \$15.95; Deluxe Model (makes 600 tests), $\$ 29.95$, postpaid.

\section{Eézin Wear}

Economical, durable and dirtproof all leather garden gloves. Soft as kid. Washable. Sizes 6, 7, 8, 9 and 10 . $\$ 1.75$ per pair, postpaid.

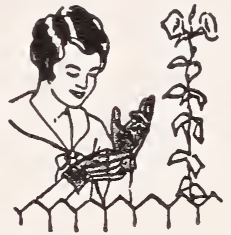

Use GREEN THUMB Gloves in the garden Sizes-Small and Medium $\$ 1.00$ per pair

\section{INSECTICIDES . . .}

\section{FUNGICIDES}

\section{GARD-N-GUN}

A sturdy, inexpensive small size sprayer. Jar holds enough to make 3 gals. of any spray. Has 1 univerisal jet; cleans in 30 seconds; guaranteed. Instead of pistol grip and trigger, has simple Touchomatic control; flips on and

off. Price, $\$ 2.69$.

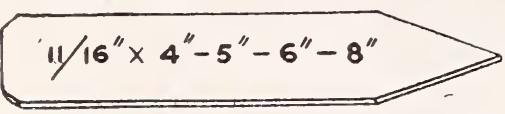

WOODEN-For pots, painted.

$\begin{array}{llll}100 & 1000 & 100 & 1000\end{array}$

5-in. .....\$ $.65 \$ 4.65 \quad 8$-in. $\ldots . . \$ .90 \quad \$ 7.60$

6-in. ...... $.75 \quad 5.15$

\section{"EVERLAST" PLANT LABELS}

The Everlast Double Foil Aluminum Plant Label outlasts all other tags. Markable with any ordinary pencil, and provides a permanent weatherproof record for plants.

Package of 24 labels ......................................55c Package of 50 labels Postpaid

RAFFIA-Its principal use is for tying vines, flowers, asparagus and celery bunches and for grafting. Natural color is a light straw. $1 \mathrm{lb}$. 60c; 5 lbs. \$2.50, postpaid.

PEERLESS GLAZING POINT-The most durable, reliable and cheapest in the market. Made of steel wire, two points, they never bend in the middle when driven or work out by wear. Sold in boxes of 1,000 which will glaze 50 lights of glass. \$1.50 per 1,000, postpaid.

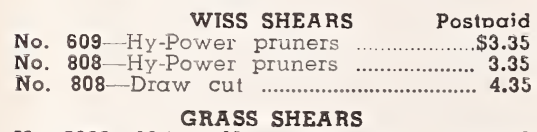

No. 5600-12-in., Narrow blad

No. $700-12$ in., Quick trim

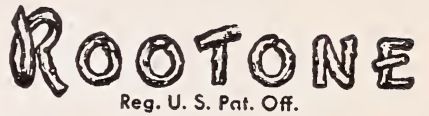

Rootone is a root-forming stimulant. When applied to cuttings, seeds or bulbs it promotes root forming in much shorter time and minimizes the loss due to slow rooting or sprouting. $1 / 4$ oz. $25 \mathrm{c} ; 2$ oz. $\$ 1.00 ; 1 \mathrm{lb}$. $\$ 5.00$, postpaid.

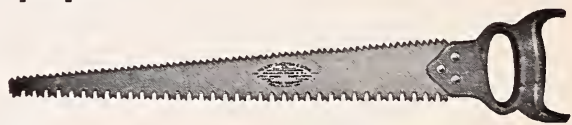

DUPIEX PRUNING SĀW $18^{\prime \prime}$ $\$ 4.95$

\section{TWIST-EMS}

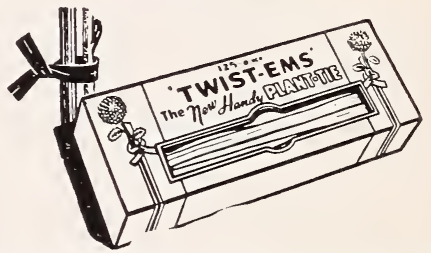

The new handy plant-tie. Simply put around stem ond support, twist and it is tied. Box of $100-8$ inch, 29c; 16 inch, $59 \mathrm{c}$, postpaid.

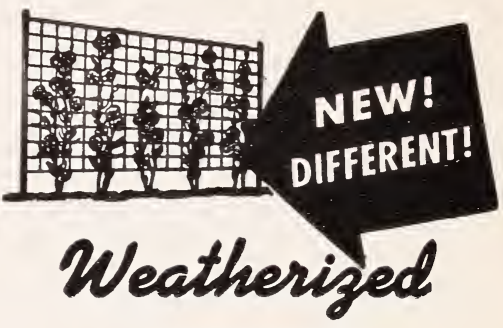

TRAINETTES

A strong and easy to use trellis for Sweet Peas and other light climbing vines. Helgh 5 feet. 6 foot length $75 \mathrm{c}$; 8 feet $95 \mathrm{c}$; 15 feet $\$ 1.35$, postpaid.

Place HOTKAPS patented paper hothouses - over seeds or plants. Complete protection from destructive FROSTS, STORMS AND INSECTS. Ripen crops 3 weeks earlier; in. crease yield $18 \%$ to $51 \%$. Maintain perfect mulch. Millions used by successful growers every season. Easy to set. 25 HOTRAPS for 95c. 250 for $\$ 7.15$, setter free; 1,000 for $\$ 19.75$; 100 for $\$ 3.90$.

\section{Germaco}

\section{RAIN canit harm}

HOT K A P S 


\section{STECKLER'S EVERBLOOMING BUSH ROSES}

\section{All two-year field grown vigorous plants}

Set out roses early in a well prepared bed. The soil must be well drained and well fertilized. Apply fertilizer to the top of the soil. Plant early for best results. $G \& O$ is the perfect rose fertilizer.

\section{BUSH VARIETIES}

\section{WHITE HARDY GARDEN ROSES}

CALEDONIA-(H. T.) Long pointed white buds, double, an exquisite rose.

KÄISERIN AUGUSTA VICTORIA-(H. T.) PuIE white, with shadings of primrose-yellow.

F. K. DRUSCHKI-Large double white, also known as White Ämerican Beauty.

\section{PINK HARDY GARDEN ROSES}

THE DOCTOR-Bud very large, long pointed flower $41 / 2$ inches across, high center, last ing, moderate fragrance, rose-pink.

RADIANCE-(H. T.) Brilliant rose-pink buds, opening in well-formed shining flowers with lighter tints on the reverse of the petals; globular in shape and very fragrant. The plant makes splendid growth has wonderful blooming qualities.

EDITOR McFARLAND - Shapely buds and double, brilliant pink blooms, profuse bloomer.

BRIARCLIFF - (H. T.) Bud one-third longer than Columbia, very large, pointed flow er $41 / 2$ inches across, high center, lasting moderate fragrance, deep rose-pink a center, passing to lighter on outer petals.

\section{YELLOW HARDY GARDEN ROSES}

GOLDEN DAWN - (T.) Pale, lemon-yellow, deepening in the center of its perfectly formed fragrant flower. Moderate growth and bloom. One of the hardiest and most beautiful Tea Roses; best in autumn.

GOLDEN CHARM-Strong, tall, free branching bush, has long, tight slender buds and always perfect. Chrome yellow in color.

SOEUR THERESE-Strong, tall, free branching bush, has long, tight slender buds and always perfect. Chrome yellow in color.

ECLIPSE-Chrome yellow, slender urnshaped, sometimes about two inches long. Vigorous, erect in habit and well foliaged.

\section{TRI-COLORED ROSES (Bush)}

PRESIDENT HOOVER-(H.T.) The rose of wonderful colors. It is remarkable for its vigorous growth and beautiful colorings. A blend of orange and pink, varying in tone from coppery-orange and pink, to glowing orange-yellow at the base of the petals, suffused with vivid rose pink.

TALISMAN-It is a combination of shadings of gold, apricot, yellow, deep pink and old rose. The bud is long, well formed and develops into full double flowers. The plant is a strong grower, with glossy green foliage and free flowering.

CONDESA DE SĀSTAGO-Glowing orangescarlet on the inside of the petals and an intensely bright yellow on the outside. of very fine quality and qood for cutting.

\section{RED HARDY GARDEN ROSES}

CRIMSON GLORY-Beautifully shaped buds open into big flowers of velvety red richly shaded with maroon. Vigorous low spreading plant.

ETOILE DE HOLLANDE-(H. T.) Bright crim son, fiery-red center cup-shaped. Free in bloom.

POINSETTIA-Color is a dazzling scarlet shading to deeper red. Originator claims it never turns puprle. Undoubtedly a fine red rose.

RED RADIANCE-(H. T.) An even bttter Rose than its parent, Radiance, in habit, bearing big, globular flowers of deep rose-red on strong, individual canes which are freely produced all summer until frost.

BETTER TIMES-(H.T.) Glorious red color, prized for its long stems and pointed buds. Large blooms.

\section{FLORIBUNDAS}

F L O R A D O R A. Perfect camellia-shaped blooms of bright cinnabar-red. Very vigorous growth; free flowering.

CECILE BRUNNER-Beautiful little buds and very double, rose-pink flowers. An ideal buttonhole rose.

\section{HARDY CLIMBING ROSES}

CL. ETOILE de HOLLANDE-(H. W.) Red. A hardy disease-resistant variety; vigorous growth and great freedom of bloom. GOLDEN CLIMBER-Immense deep golilenyellow flowers with the deepest, richest tea fragrance of all roses.

PAUL'S SCARLET CLIMBER-(H. W.) Vivid scarlet, shaded crimson, makes a brilliant display for a long period of time in the garden. A wonderful climbing rose.

CL. RED RADIANCE (Cl. H. T.) Exactly like the bush variety of the same name except that it is of climbing habit.

CL. PINK RADIANCE-One of the finest climbers in a good pink.

CL. TALISMAN-Same as the bush variety, strong growing and free blooming.

CL. BLAZE. Marvelous hardy everblooming scarlet red rose. Blooms from early sprino until late autumn.

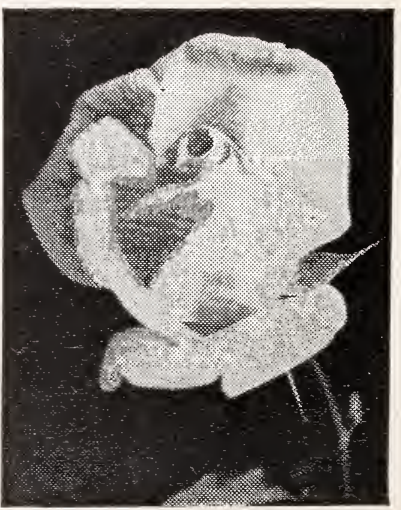

Pink Radiance 


\section{PATENTED ROSES}

\section{BUSH}

MIRANDY-Deep rich red; fragrant, produces freely on strong, upright stems. One to be added to your rose collection. Price \$2.25.

PEACE-One of the most appealing roses ever introduced. Coppery pink in bud form but when open fully rose is of the softest yellow with pink edging. Price $\$ 2.50$.

NOCTURNE - Cardinal red, long, perfect buds, pleasing fragrance, blooms over a long season. Price \$2.25.

CHARLOTTE ARMSTRONG - Deep cerise; beautiful for cutting; long stems. Price $\$ 2.25$.

TIFFANY - AARS for 1955 (Hybrid Tea). Phlox pink with an alluring scent and lasting quality. Price $\mathbf{\$ 2 . 5 0 \text { . }}$

FORTY-NINER - Bi-color, yellow outside and bright red within. Fragrant. Price \$2.25.

LOWELL THOMAS - Lemon blooms, lasts very well, upright grower with lovely fragrance. Price $\$ 2.25$.

NEW YORKER-A red rose that stays red, upright growing and long blooming. Price \$2.25.

MOJAVE-One of the finest orange colored roses yet introduced, typical of a desert sunset-glowing orange shot with flamelike tones of scarlet and vermillion.

Price \$2.75.

HELEN TRAUBEL-It is a blend of warm pink and apricot with a bright undertone which makes the color sparkle. Long, exquisite buds. Price \$2.75.

CHRYSLER-Lively glowing crimson, with an abundance of rich perfume, beautiful in bud and open flower. Price \$2.50.

QUEEN ELIZABETH-AARS for 1955-Grandiflora. Glowing pure pink. Blooms will frequently occur singly on long almost thornless stems, even those occurring in clusters have long enough stems for cut flower uses. Price \$2.50.

CIRCUS-(Pat. 1382.) All America Winner for 1956. Has gay bright flowers in an array of colors, from rich yellow and red in the bud to orange-buff flushed pink in the open bloom. \$2.50 each.

\section{CLIMBERS}

CL. PEACE-Palest yellow flushed pinklike the bush Peace Rose, but a wonderful climbing plant. Will make a showplace of your garden. \$2.25 each.

Add 25c Per Bush for Postage on All Patented Roses.

\section{ROSETONE}

Insures the success of your roses. Soak roots of bushes in Rosetone before planting. Water your established rose bushes for better growth.

11/2-oz. packet 25c; 3-oz. package $\$ 1.00$.

\section{ACME ROSE DUST}

\section{A Rose Lover's Dream}

A potent insecticide-fungicide formulation for control of important rose pests. Captan $(7 \%)$ for black spot; Karathane $(.75 \%)$ for powdery mildew; Malathion $(4 \%)$ for aphids, thrips, spider mites, mealy bugs, tarnish plant bugs, lacebugs: and DDT $(5 \%)$ for rose chafer, and other beetles and caterpillars. Effective as a dust or spray.

8 oz. gun $\$ 1.25 ; 2$ lbs. $\$ 2.40$.
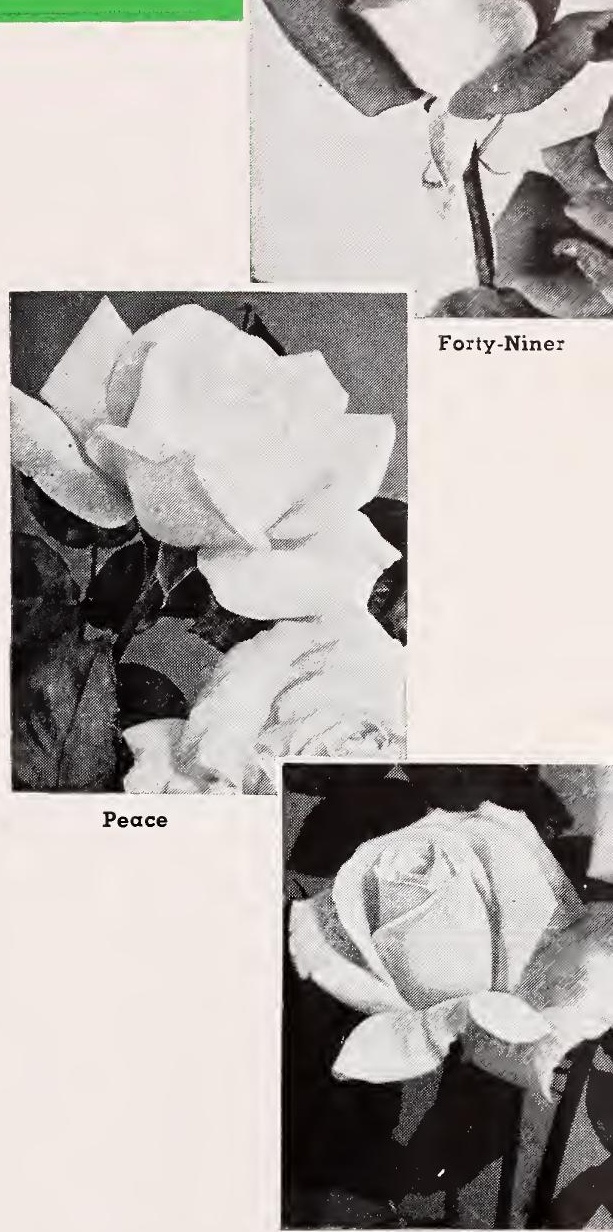

Lowell Thomas

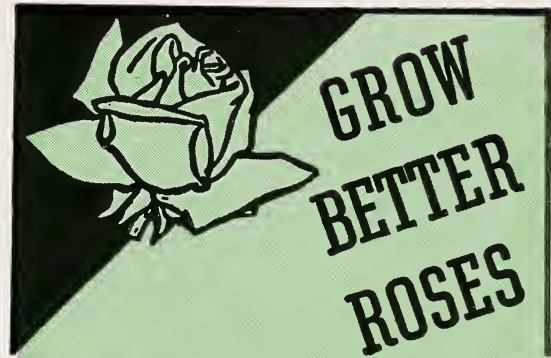

Spray with TRI-OGEN - the Rose Garden Spray Treatment for the control of many insects and fungus pests. Also an effective stimulant which tends to promote healthy plant growth. Four sizes-\$2.50, $\$ 6.25, \$ 9.95$ and $\$ 30.00$.

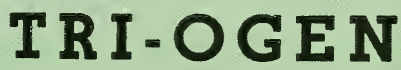

Patents Pending 


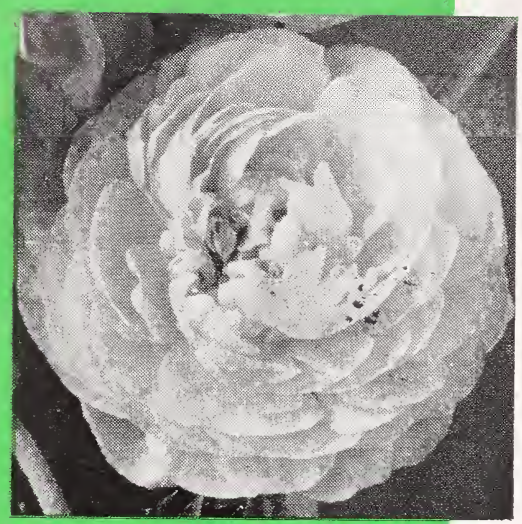

RANUNCULUS

THE

SOUTH'S

BEST

SEEDS

SUMMER

AND

FALL

1958

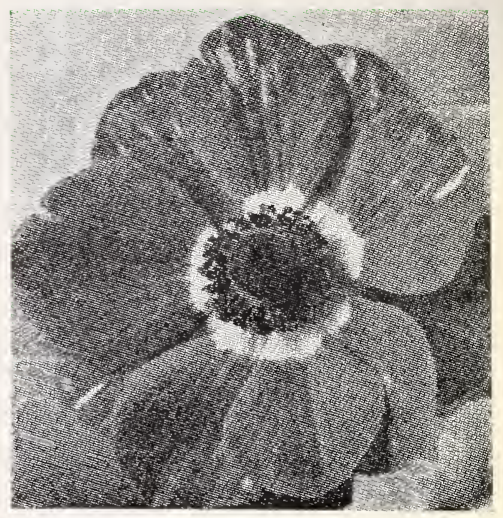

ANEMONE

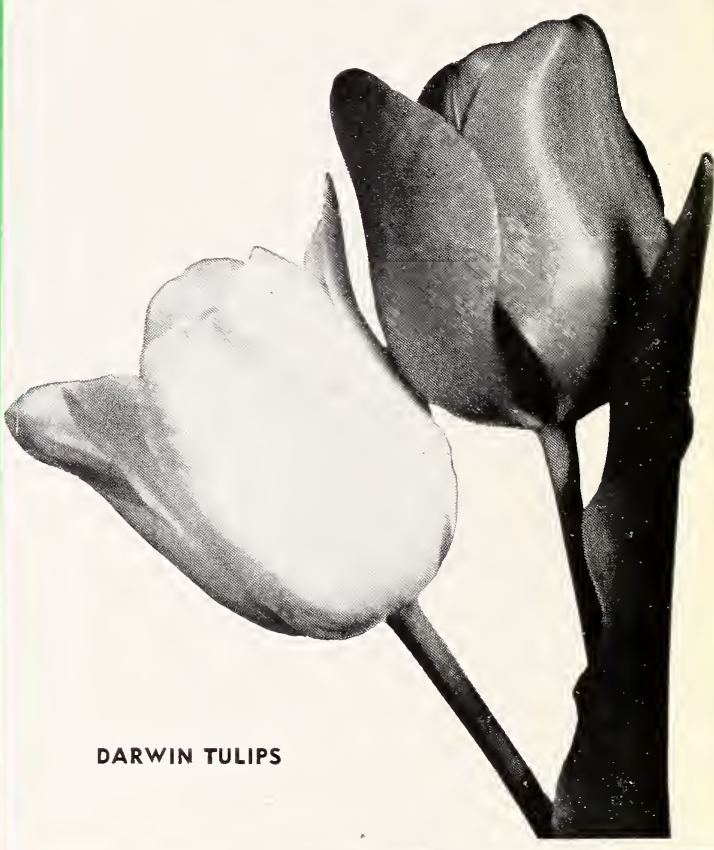

STECKLER SEED COMPANY INC. 512 GRAVIER STREET NEW ORLEANS 3, LA.

DAFFODILS

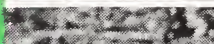

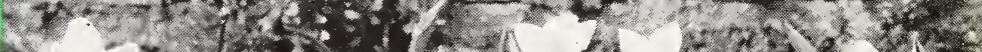

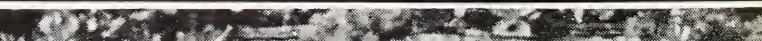

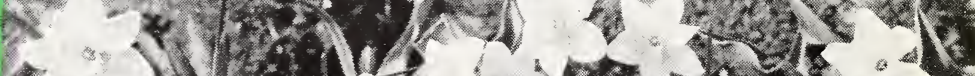

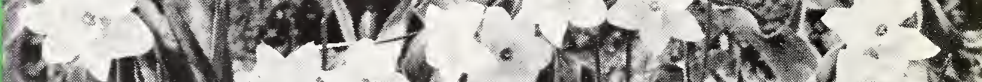

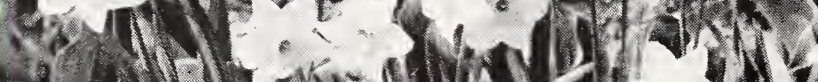

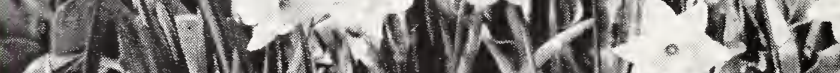
(5)

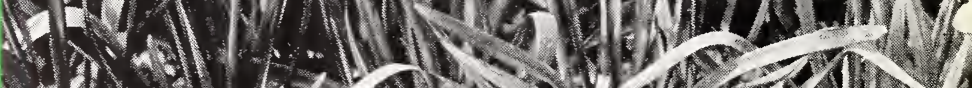
atias Nyitre 1.1. $x$

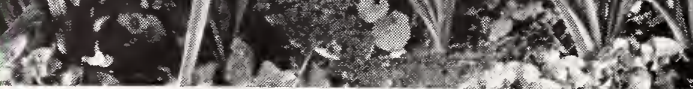

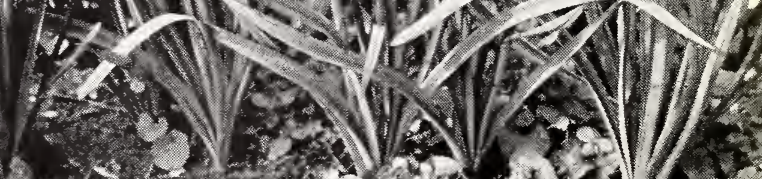

